-1 -

\title{
Subtropical Frontal Zone of the Southern Ocean
}

\author{
Igor M. Belkin ${ }^{1}$ \\ ${ }^{1}$ College of Marine Science and Technology, Zhejiang Ocean University, Zhoushan 316022, China \\ igormbelkin@gmail.com \\ Submitted 2021-06-03 \\ to the Special Issue on Remote Sensing for Fisheries and Aquaculture of Remote Sensing (MDPI)
}

\section{Contents}

Abstract

1. Introduction

2. Circumpolar STFZ from WOCE sections

3. South Atlantic

4. South Indian Ocean

5. Tasman Sea

6. New Zealand sector

7. Central South Pacific

8. Southeast Pacific

9. South Pacific STFZ and the ecology of Chilean jack mackerel

10. Discussion

11. Summary

Acknowledgments

Data statement

References

\begin{abstract}
This paper combines a literature survey and data analysis. The literature on the Subtropical Front (STF) in the Southern Ocean is reviewed with a two-pronged emphasis on the double-front structure of the STF, hence the existence of a subtropical frontal zone (STFZ), and the circumpolar continuity of the STFZ. The data analysis is based on the World Ocean Circulation Experiment (WOCE) sections. The STFZ is detected along each section independently from other sections, while moving circum-polarly downstream (eastward). The literature survey and data analysis confirm the circumpolar continuity of the STFZ extending from the Brazil Current across the South Atlantic, South Indian, and South Pacific up to Chile, being bound by the North and South STF. The circumpolar continuity of the STFZ is partly interrupted by South Africa and Tasmania, where the North STF ceases, while the South STF continues eastward. The South Atlantic STFZ is the southern boundary of the well-defined Subtropical Mode Water (STMW) thermostad, which cools eastward from $15^{\circ} \mathrm{C}$ to $11^{\circ} \mathrm{C}$ between the Brazil Current and Greenwich Meridian. In the southeast Pacific, the STFZ is the southern boundary of the 17 -to- $19^{\circ} \mathrm{C}$ thermostad (South Pacific Eastern STMW). The STFZ's vertical extent is at maximum in the South Atlantic ( $>1000 \mathrm{~m}$ ), decreasing eastward to $300 \mathrm{~m}$ in the southeast Pacific off Chile. A special attention is given to the South Pacific and the STFZ's role in the ecology of Chilean jack mackerel Trachurus murphyi that spawn at the STFZ and migrate along the STFZ from Chile up to New Zealand.
\end{abstract}


-2 -

Keywords: Front, Southern Ocean, Subtropical Front, Subtropical Convergence, Subtropical Frontal Zone, Subtropical Mode Water, Front detection, Remote sensing, Satellite oceanography, Marine ecology, Fisheries, Chilean jack mackerel, Trachurus murphyi

\section{Introduction}

An increased meridional gradient of sea surface temperature in the subtropical-subantarctic latitudinal belt (roughly $30^{\circ} \mathrm{S}$ to $45^{\circ} \mathrm{S}$ ) was noticed long ago during voyages of sailing vessels. In a comprehensive literature survey of the South Atlantic upper-layer circulation, Ray Peterson and Lothar Stramma credited Otto Krümmel with the discovery of the Subtropical Front (STF) in the South Atlantic based on numerous measurements from sailing vessels in the mid-19 ${ }^{\text {th }}$ century (Peterson and Stramma, 1991, p. 40):

"The STF was identified by Krümmel (1882) as being a sharp discontinuity in surface temperature which he found to stretch across most of the South Atlantic from its origins in the Brazil-Falkland Confluence Zone."

In another great review ("Early concepts and charts of ocean circulation"), Peterson, Stramma and Kortum (1996, p. 106) wrote:

"Krümmel (1882) traced the western and southern wall of the Brazil Current, finding that... the current makes an abrupt turn to the ENE south of $45^{\circ} \mathrm{S}$, and that sharp temperature contrasts exist across it to as far as $40.5^{\circ} \mathrm{S} 9^{\circ} \mathrm{W}$... This apparently was the first basin-scale, explicit description of what later came to be called the Subtropical Convergence and more recently the Subtropical Front, though a convergence of surface waters had been shown on maps in about the same location beginning with those by Wilkes (1845) and Findlay (1853)."

The circumpolar nature of the Southern Ocean STF was recognized early on (Deacon, 1937, 1982). However, systematic regional studies of this front began in earnest only in the 1980s1990s, when Lothar Stramma and collaborators investigated the South Atlantic Current and associated STF (Stramma and Peterson, 1990), South Indian Ocean Current and associated STF (Stramma, 1992; Stramma and Lutjeharms, 1997), and South Pacific Current and associated STF (Stramma et al., 1995). The above studies emphasized the density-compensated nature of the STF that resulted in a spatial discordance between the STF's manifestations in temperature and salinity vs. that in velocity field. Meanwhile, Belkin (1988) documented the STF in the South Pacific between New Zealand and $126^{\circ} \mathrm{W}$, where the STF was found to consist of two parallel fronts 400-500 km apart, termed the North and South STF (NSTF and SSTF respectively), that border the Subtropical Frontal Zone (STFZ). In a follow-up study, Belkin (1993) documented a similar double-front STFZ in the South Atlantic. Finally, during a comprehensive study of the Southern Ocean fronts between $0^{\circ}$ and $150^{\circ} \mathrm{E}$, Belkin and Gordon (1996) have discovered a previously unknown front (termed the North STF) in the South Indian Ocean between $31^{\circ} \mathrm{S}$ and $35^{\circ} \mathrm{S}$, north of the well-known STF (now the South STF), and thereby established a circumpolar double-front Subtropical Frontal Zone.

The double-front structure of the Southern Ocean STFZ documented by Belkin (1988), Belkin et al. (1988a), Belkin et al. (1988b), Belkin (1993), and Belkin and Gordon (1996) was corroborated in the South Atlantic (Smythe-Wright et al., 1998; Burls and Reason, 2006; Juliano and Alves, 2007; Dencausse et al., 2011), South Indian Ocean (Holliday and Read, 1998; Kostianoy 
et al., 2004; Anilkumar et al., 2006; He et al., 2006; Luis and Sudhakar, 2009), and South Pacific (Sutton, 2001; Smith, 2017). The double-front STFZ appears to be a global phenomenon, which is by now well-documented in both hemispheres. During a global survey of SST fronts from satellite data, Belkin et al. (1998) found double-front STFZs in the Southern Ocean, North Atlantic, and North Pacific. In the Sargasso Sea, multiple thermal fronts inside the Subtropical Convergence Zone were first reported in the 1960s (Voorhis, 1969), followed up by observations of a double-front STFZ (McCleave, 1993; Miller and McCleave, 1994; Munk et al., 2010). Multiple STFs in the western and central North Pacific were described and reviewed by Kobashi et al. (2006), while Villareal and Wilson (2014) reported two subtropical fronts in the eastern North Pacific.

The circumpolar continuity of the Southern Ocean STFZ is interrupted by the South American continent between roughly $75^{\circ} \mathrm{W}$ and $55^{\circ} \mathrm{W}$. The African continent blocks the NSTF in the SE Atlantic (Belkin and Gordon, 1996), while the SSTF slips south of Africa from the SE Atlantic to the SW Indian Ocean. In the SE Indian Ocean, the NSTF and SSTF merge into a single STF south of Australia. This front continues across the Tasman Sea toward the southern extremity of New Zealand's South Island, where this front is known as the Southland Front, which continues as the South STF for $>10,000 \mathrm{~km}$ toward Chile. Meanwhile, the NSTF in the SW Pacific is restored as a continuation of the East Australian Current (EAC) after the EAC leaves the coast and extends eastward across the northern Tasman Sea, where it is known as the Tasman Front. Farther east, the Tasman Front continues around the northern tip of New Zealand's North Island and becomes the East Auckland Current and East Cape Current before the latter aligns with the northern flank of the Chatham Rise and continues eastward across the South Pacific as the North STF. Some elements of the above schematic description are debatable and will be discussed below in respective regional sections.

The issue of oceanographic continuity of any front is critically important for the front tracking across vast expanses of the ocean because the continuity allows frontal criteria to be gradually adjusted downstream along the front as efficiently demonstrated by Belkin and Gordon (1996) who tracked major large-scale fronts of the Southern Ocean across a 150-degree longitudinal span. Most importantly, Belkin and Gordon (1996) emphasized the importance of structural criteria in front detection, mapping, and tracking. Each large-scale front is a boundary between two regions ("zones") that feature different types of vertical structure (stratification). Each type is characterized by a unique combination of extrema of temperature and salinity and their derivatives that are stacked vertically. For example, the Antarctic Zone features a well-defined subsurface temperature minimum between $100 \mathrm{~m}$ and $300 \mathrm{~m}$ depth. Therefore, the northern boundary of the Antarctic Zone (called the Antarctic Polar Front) is best detected as the northern terminus of the subsurface temperature minimum. Another example is the Subantarctic Zone that features a thick subsurface thermohalostad (vertically uniform layer) known as the Subantarctic Mode Water, SAMW. Therefore, the southern boundary of the Subantarctic Zone (known as the Subantarctic Front) is best detected as the southern boundary of the SAMW. The superiority of structural criteria was demonstrated by Belkin and Gordon (1996) by reliably tracking all major fronts of the Southern Ocean from the Greenwich Meridian to Tasmania. The robustness of structural criteria contrasts with limited reliability of fixed numerical criteria that are usually formulated for specific regions and must be adjusted in the along-front direction 
$-4-$

("downstream"). A comprehensive summary of such fixed numerical criteria has been compiled by Belkin and Gordon (1996).

The current proliferation of regional studies of the STF warrants a circumpolar review of the literature. At the same time, the availability of a top-quality data set acquired during the World Ocean Circulation Experiment (WOCE) presents an opportunity for a data analysis that complements and reinforces conclusions made during an analytic survey of the literature. In this study the STFZ was tracked from the SW Atlantic to the SE Pacific using the CTD sections collected during WOCE. While dealing with cross-frontal vertical oceanographic sections, structural criteria were favored. For example, emergence or disappearance of a thermostad associated with a mode water or a stepwise change of the thermostad's temperature across a short distance are robust diagnostic signatures of a front. Numerical criteria were used occasionally to complement front detection based on structural criteria. The STF was sought as a maximum horizontal gradient of salinity within salinity ranges determined in previous studies (Deacon, 1982; Belkin, 1988; Stramma and Peterson, 1990; Stramma, 1992; Stramma et al., 1995; Orsi et al., 1995; Belkin and Gordon, 1996).

The structure of this paper is as follows:

1. Section 2 covers the circumpolar STFZ from WOCE sections.

2. Section 3 covers the South Atlantic.

3. Section 4 covers the South Indian Ocean.

4. Section 5 covers the Tasman Sea.

5. Section 6 covers the New Zealand sector.

6. Section 7 covers the Central South Pacific.

7. Section 8 covers the Southeast Pacific.

8. Section 9 covers the STFZ's role in the ecology of Chilean jack mackerel.

9. Section 10 covers Discussion.

10. Section 11 covers Summary.

\section{Circumpolar STFZ from WOCE sections}

The World Ocean Circulation Experiment (WOCE) Atlas (http://woceatlas.ucsd.edu/) was used to identify the STFZ along meridional sections of temperature and salinity. The results are presented from west to east, starting with the Atlantic Ocean (WOCE Atlas Vol. 3, https://doi.org/10.21976/C6RP4Z), followed by the Indian Ocean (WOCE Atlas Vol. 4, https://doi.org/10.21976/C61595) and Pacific Ocean (WOCE Atlas Vol. 2, https://doi.org/10.21976/C6WC77). The S3 section along $150^{\circ} E$ is from the WOCE Southern Ocean Atlas (WOCE Atlas Vol. 1, https://doi.org/10.21976/C6BC78). Table 1 summarizes the results of our analysis.

Table 1. WOCE sections across the STFZ in the Southern Ocean

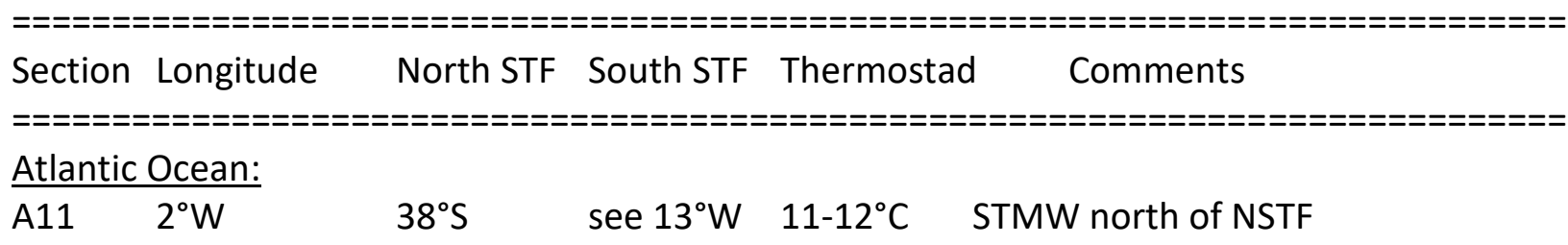


-5 -

\begin{tabular}{|c|c|c|c|c|c|}
\hline A11 & $13^{\circ} \mathrm{W}$ & see $2^{\circ} \mathrm{W}$ & $43-44^{\circ} \mathrm{S}$ & NA & Slant section \\
\hline A12 & $11^{\circ} \mathrm{E}$ & NA & $40^{\circ} \mathrm{S}$ & NA & Good Hope line \\
\hline A13 & $10^{\circ} \mathrm{E}$ & NA & $38-40^{\circ} \mathrm{S}$ & NA & V-shaped route; Good Hope line \\
\hline A14 & $9^{\circ} \mathrm{W}$ & $37^{\circ} \mathrm{S}$ & $42^{\circ} \mathrm{S}$ & $12-13^{\circ} \mathrm{C}$ & STMW north of NSTF \\
\hline A15 & $19^{\circ} \mathrm{W}$ & NA & NA & NA & North of the North STF \\
\hline A16 & $27-33^{\circ} \mathrm{W}$ & $34^{\circ} \mathrm{S}$ & $42^{\circ} \mathrm{S}$ & $13-14^{\circ} \mathrm{C}$ & STMW north of NSTF \\
\hline A17 & $40-45^{\circ} \mathrm{W}$ & $35^{\circ} \mathrm{S}$ & $41^{\circ} \mathrm{S}$ & $15^{\circ} \mathrm{C}$ & STMW north of NSTF \\
\hline A23 & $35-36^{\circ} \mathrm{W}$ & $38^{\circ} \mathrm{S}$ & $42^{\circ} \mathrm{S}$ & $14-15^{\circ} \mathrm{C}$ & STMW north of NSTF \\
\hline \multicolumn{6}{|c|}{ 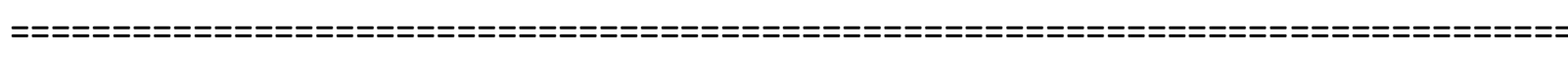 } \\
\hline \multicolumn{6}{|c|}{ Indian Ocean: } \\
\hline 106 & $30^{\circ} \mathrm{E}$ & $37^{\circ} S^{*}$ & $42^{\circ} \mathrm{S}$ & $17^{\circ} \mathrm{C}^{*}$ & *Agulhas Front \\
\hline 107 & $45-55^{\circ} \mathrm{E}$ & NA & NA & NA & This section is north of the STFZ \\
\hline 108109 & $95^{\circ} \mathrm{E}$ & $34^{\circ} \mathrm{S}$ & $44^{\circ} \mathrm{S}^{*}$ & $10^{\circ} \mathrm{C} * *$ & *SSTF-SAF merger? **SAMW \\
\hline I08N & $85-90^{\circ} \mathrm{E}$ & NA & NA & NA & This section is north of the STFZ \\
\hline I09S & $115^{\circ} \mathrm{E}$ & NA & $40^{\circ} \mathrm{S}$ & $9^{\circ} \mathrm{C}$ & SAMW north of SAF; Single STF? \\
\hline S3 & $150^{\circ} \mathrm{E}$ & NA & $46^{\circ} \mathrm{S}$ & $8-9^{\circ} \mathrm{C}$ & SAMW north of SAF \\
\hline \multicolumn{6}{|c|}{ 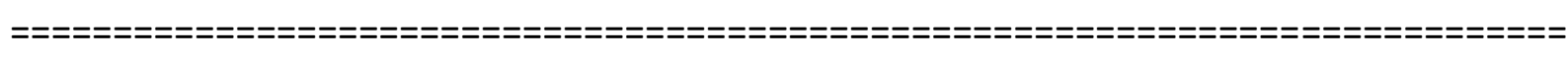 } \\
\hline \multicolumn{6}{|c|}{ Pacific Ocean: } \\
\hline P11 & $155^{\circ} \mathrm{E}$ & $30^{\circ} \mathrm{S}$ & $46^{\circ} \mathrm{S}$ & & North STF = Tasman Front \\
\hline P14 & $175^{\circ} \mathrm{E}$ & $34^{\circ} \mathrm{S}$ & NA & & North STF = Tasman Front \\
\hline P15 & $170^{\circ} \mathrm{W}$ & $42^{\circ} \mathrm{S}$ & $48^{\circ} \mathrm{S}$ & & SSTF swings south toward SAF \\
\hline P16 & $150^{\circ} \mathrm{W}$ & $33^{\circ} \mathrm{S}$ & $38^{\circ} \mathrm{S}$ & & NSTF and SSTF extend ENE \\
\hline P17 & $135^{\circ} \mathrm{W}$ & $35.5^{\circ} \mathrm{S}$ & $37.5^{\circ} \mathrm{S}$ & & STFZ is nearly zonal in this sector \\
\hline P18 & $103^{\circ} \mathrm{W}$ & $28.5^{\circ} \mathrm{S}$ & $33.5^{\circ} \mathrm{S}$ & $19^{\circ} \mathrm{C}$ & STMW north of NSTF \\
\hline P19 & $88^{\circ} \mathrm{W}$ & $29^{\circ} \mathrm{S}$ & $34^{\circ} \mathrm{S}$ & $17^{\circ} \mathrm{C}$ & STMW north of NSTF \\
\hline
\end{tabular}

\section{A17 section along $40-45^{\circ} \mathrm{W}$ :}

This section extends NE-SW parallel to the east coast of South America. It crosses the BrazilMalvinas Confluence of the warm and saline Brazil Current with the cold and fresh Falkland/Malvinas Current. The Brazil Current Retroflection forms meanders and anticyclonic rings that greatly complicate analysis of oceanographic sections across the Confluence; the A17 section (analyzed by Mémery et al., 2000) is no exception. Nonetheless, the North STF (Brazil Current Front, BCF) is reliably detected at $35^{\circ} \mathrm{S}$, with a well-defined $15^{\circ} \mathrm{C}$ thermostad north of the North STF. The South STF is at $41^{\circ} \mathrm{S}$. The entire STFZ between the North and South STF is filled with meanders/rings of the Brazil Current.

\section{A23 section along $35-36^{\circ} \mathrm{W}:$}

This meridional section has crossed the North STF at $38^{\circ} \mathrm{S}$ and South STF at $42^{\circ} \mathrm{S}$. The STMW thermostad north of the North STF is colder $\left(14-15^{\circ} \mathrm{C}\right)$ than that along the A17 section just a few hundred km west. Tropical waters north of the North STF are quite saline, with SSS>35.7 psu. Vertical extent of the North STF exceeds $1000 \mathrm{~m}$, which is evident in the temperature distribution, where even at $700 \mathrm{~m}$ depth the cross-frontal horizontal temperature range exceeds $5^{\circ} \mathrm{C}$. This section is analyzed by Heywood and King (2002) who placed the Brazil Current Front (BCF) at 
$-6-$

$38^{\circ} \mathrm{S}$, where the BCF coincides with the North STF. Farther south, according to Heywood and King (2002), the STF (our South STF) formed a S-shaped meander (that "may be caused by the eastern end of the circulation around the Zapiola Rise" (ibid., p. 640)), which was crossed by the A23 section three times, with the southernmost crossing at $44-45^{\circ} \mathrm{S}$ (ibid., p. 640 and Fig. 1), albeit the southernmost crossings appear like a section across a ring detached from the front.

\section{A16 section along $27-33^{\circ} \mathrm{W}:$}

This section (analyzed by Tsuchiya, Talley, and McCartney, 1994) crossed the North STF at $34^{\circ} \mathrm{S}$ and South STF at $42^{\circ} \mathrm{S}$. North of the North STF, the STMW $13-14^{\circ} \mathrm{C}$ thermostad is colder than the $14-15^{\circ} \mathrm{C}$ thermostad at the $\mathrm{A} 23$ section $\left(35^{\circ} \mathrm{W}\right)$, which is colder than the $15^{\circ} \mathrm{C}$ thermostad at the A17 section $\left(40-45^{\circ} \mathrm{W}\right)$. Thus, the STMW thermostad is cooling eastward along the STFZ. Between the North and South STF, a much colder $11-12^{\circ} \mathrm{C}$ thermostad is found.

\section{A15 section along $19^{\circ} \mathrm{W}$ :}

This section stopped short of the North STF. There is a TS-front at $31^{\circ} \mathrm{S}$; however, this front is not the North STF as evidenced by the absence of the STMW thermostad north of this front.

\section{A14 section along $9^{\circ} \mathrm{W}$ :}

Along this line, there are three fronts within the subtropical belt: at $33^{\circ} \mathrm{S}, 37^{\circ} \mathrm{S}$, and $42^{\circ} \mathrm{S}$. North of the $33^{\circ} \mathrm{S}$ front, the extremely warm and thick $17^{\circ} \mathrm{C} / 35.7$ psu thermohalostad likely belongs to a warm anticyclonic Agulhas ring; this is one of the rings tracked by Schouten et al. (2000). The $37^{\circ} \mathrm{S}$ front is the North STF. The $12-13^{\circ} \mathrm{C}$ thermostad north of the North STF is colder than the 13$14^{\circ} \mathrm{C}$ thermostad at the $\mathrm{A} 16$ section farther west, thereby maintaining the eastward cooling trend of the STMW thermostad along the STFZ. The $42^{\circ} \mathrm{S}$ front is the South STF. The STFZ extends vertically deeper than $1000 \mathrm{~m}$.

A13 sections (slant section SW of Cape Town; $10^{\circ} \mathrm{E}$ section): The V-shaped route had the turning point at $40^{\circ} \mathrm{S}, 10^{\circ} \mathrm{E}$ (Sta.130), apparently in the vicinity of the South STF. Eddies north and NE of Sta.130 greatly complicate interpretation of the $A 13$ sections.

\section{A12 slant section SW of South Africa:}

There is no North STF along this transect ("Good Hope line"). The South STF is at $40^{\circ} \mathrm{S}$.

\section{A11 slant section SW of South Africa (north of the Good Hope line):}

This section has crossed the STFZ close to the A14 section. The North STF is at $38^{\circ} \mathrm{S}, 2^{\circ} \mathrm{W}$. The 11 $12^{\circ} \mathrm{C}$ thermostad north of the North STF is colder than its upstream counterpart at $9^{\circ} \mathrm{W}$ (section A14), consistent with the eastward cooling trend of the STMW thermostad. The South STF is at $43-44^{\circ} \mathrm{S}, 13^{\circ} \mathrm{W}$. The STFZ features a cold $9^{\circ} \mathrm{C}$ thermostad between the North and South STF, inside the STFZ.

\section{6 section along $30^{\circ} \mathrm{E}$ :}

The Agulhas Front is at $37^{\circ} \mathrm{S}$. The South STF is at $42^{\circ} \mathrm{S}$. There is a warm Agulhas ring between the Agulhas Front and South STF. At this longitude, the North STF is not present yet (Belkin and Gordon, 1996, Fig. 4). 
- 7 -

\section{7 section along $45-55^{\circ} \mathrm{E}$ :}

This section is located north of $34^{\circ} \mathrm{S}$ that is north of the STFZ (Belkin and Gordon, 1996).

\section{$108 \mathrm{~N}$ along $85-90^{\circ} \mathrm{E}$ :}

This section is located north of $30^{\circ} \mathrm{S}$ that is north of the STFZ (Belkin and Gordon, 1996).

\section{9 section along $95^{\circ} \mathrm{E}:$}

The North STF is at $34^{\circ} \mathrm{S}$. The extremely strong front at $44^{\circ} \mathrm{S}$ is likely a merger of the South STF and SAF. This front is identified as the SAF by McCartney and Donohue (2007). The $10^{\circ} \mathrm{C} \mathrm{SAMW}$ thermostad is north of this front.

\section{I09S along $115^{\circ} \mathrm{E}:$}

The South STF is at $40^{\circ} \mathrm{S}$. This front could be a merger of the North and South STF (Belkin and Gordon, 1996). The SAF is at $46^{\circ} \mathrm{S}$. McCartney and Donohue (2007) placed the SAF at $49^{\circ} \mathrm{S}$. The SAF's location ambiguity is caused by the section crossing frontal meanders/rings. The $8-9^{\circ} \mathrm{C}$ SAMW thermostad is north of the SAF.

\section{S3 slant section along $145-150^{\circ} \mathrm{E}$ SSW of Tasmania:}

The South STF is at $46^{\circ} \mathrm{S}$. The SAF is at $50^{\circ} \mathrm{S}$. The $8-9^{\circ} \mathrm{C} \mathrm{SAMW}$ thermostad is between the SAF and South STF.

\section{P11 section along $155^{\circ} \mathrm{E}$ across the southern Tasman Sea:}

This section has crossed the SAF at $52^{\circ} \mathrm{S}$, South STF at $46^{\circ} \mathrm{S}$, and Tasman Front (North STF) at $30^{\circ} \mathrm{S}$. The South STF is rather poorly defined in the southern Tasman Sea because of the density compensation across the South STF (Tippins and Tomczak, 2003; Hamilton, 2006). The North STF (Tasman Front) is complicated by meanders apparent at this section south of $30^{\circ} \mathrm{S}$. The strong meandering of the zonally-trending Tasman Front is likely caused by its interaction with the quasimeridional Lord How Rise, Norfolk Ridge, and West Norfolk Ridge crossed by the front (Stanton, 1979, 1981; Stanton and Ridgway, 1988; Tilburg et al., 2001; Oke et al., 2019a, 2019b).

P14C section along $175-179^{\circ} \mathrm{E}$ : The North STF was crossed at $34^{\circ} \mathrm{S}$ immediately north of the North Cape of the North Island, New Zealand.

\section{P15 section along $165-170^{\circ} \mathrm{W}$ across the Chatham Rise:}

This section has crossed the South STF at $48^{\circ} \mathrm{S}$ and North STF at $42^{\circ} \mathrm{S}$. The South STF's location far south, at $48^{\circ} \mathrm{S}$, is a result of the STF's quasi-stationary meandering to the south documented from in situ and satellite data (Heath, 1981; Graham and de Boer, 2013; Fernandez et al., 2014) and reproduced by numerical models (Tilburg et al., 2002; Behrens et al., 2021). The North STF's location at $42^{\circ} \mathrm{S}$ is consistent with previous observations of this front (Belkin, 1988; Sutton, 2001).

\section{P16 section along $150^{\circ} \mathrm{W}$ :}

This section has crossed the South STF at $38^{\circ} \mathrm{S}$ and North STF at $33^{\circ} \mathrm{S}$. The STFZ manifestation in salinity is exceptionally strong, with the SSS step across the STFZ exceeding 1.0 psu, from $<34.4$ 
$-8-$

at $38^{\circ} \mathrm{S}$ to $>35.4$ at $32^{\circ} \mathrm{S}$. This large salinity step occurs in three steps (fronts), with the middle front at $35.5^{\circ} \mathrm{S}$. The entire triple-front STFZ extends vertically to at least $500 \mathrm{~m}$ depth. The multicore structure of the STFZ in the South Pacific was observed by Belkin, Gritsenko, and Kryukov (1988) and Belkin, Gusev, and Levin (1988). Tsuchiya and Talley (1998) noted the "banded" STF in the SE Pacific along the P19 section $\left(88^{\circ} \mathrm{W}\right)$.

\section{P17 section along $135^{\circ} \mathrm{W}$ :}

This section has crossed the South STF at $38.5^{\circ} \mathrm{S}$ and North STF at $35^{\circ} \mathrm{S}$. Thus, the distance between the North and South STF (=STFZ width) is just 3.5 degrees of latitude. This is the narrowest segment of the circumpolar STFZ. Perhaps not coincidentally, in this sector, the meridional gradient of SSS reaches its maximum values across the entire South Pacific (e.g., Koshlyakov and Tarakanov, 2005, Fig. 6).

The northern part of $\mathrm{P} 17$ section along $135^{\circ} \mathrm{W}$ from $34^{\circ} \mathrm{N}$ to $33^{\circ} \mathrm{S}$ was occupied in JuneAugust 1991 (Tsuchiya and Talley, 1996). Along this line the STFZ has not been crossed even at the southernmost station at $33^{\circ} \mathrm{S}$ (Sta. 179), where SST was between $16-17^{\circ} \mathrm{C}$ and SSS was between 35.1-35.2. A minor front was crossed near $30^{\circ} \mathrm{S}$, where SSS dropped from 35.4 to 35.2 and SST dropped from $18^{\circ} \mathrm{C}$ to $17^{\circ} \mathrm{C}$ (ibid., Figs. 2, 3, and 9). There was no STFZ manifestation in nutrient data all way south down to $33^{\circ} \mathrm{S}$.

The southern part of P17 section along $135^{\circ} \mathrm{W}$ has crossed the STFZ between $35^{\circ} \mathrm{S}$ and $38.5^{\circ} \mathrm{S}$. The North STF at $35-36^{\circ} \mathrm{S}$ was much stronger and deeper (extending to $400 \mathrm{~m}$ depth) than the South STF at $37-38.5^{\circ}$ S. The SSS at Sta. 113 (south of the North STF) was <34.55, while at Sta. 115 (north of the North STF) the SSS was $>35.0$. The South STF (Stas. 108-111) had SSS of 34.2-34.5.

\section{P18 section along $103^{\circ} \mathrm{W}$ :}

This section has crossed the South STF at $33.5^{\circ} \mathrm{S}$ and North STF at $28.5^{\circ} \mathrm{S}$. Additional fronts appear inside and outside the STFZ, at $32^{\circ} \mathrm{S}$ and $26.5^{\circ} \mathrm{S}$. The Tropical Front is at $23^{\circ} \mathrm{S}$. The STMW thermostad appears north of the North STF for the first time during our progression along the STFZ from west to east, which is consistent with the results by Wong and Johnson (2003) who mapped the STMW in the South Pacific and termed it the South Pacific Eastern Subtropical Mode Water or SPESTMW. The STMW $19^{\circ} \mathrm{C}$ thermostad is quite warm, becoming even warmer $\left(20^{\circ} \mathrm{C}\right)$ father north.

\section{P19 section along $88^{\circ} \mathrm{W}$ :}

The P19 section along $88^{\circ} \mathrm{W}$ was first occupied in February-April 1993 (Tsuchiya and Talley, 1998). The triple-front STFZ was crossed between $28.5^{\circ} \mathrm{S}$ and $34.5^{\circ} \mathrm{S}$, with a total SSS range of approximately $1.5 \mathrm{psu}(34.0-35.5)$ across the South STF at $34-34.5^{\circ} \mathrm{S}$, Middle STF at $32^{\circ} \mathrm{S}$, and North STF at $28-28.5^{\circ} \mathrm{S}$. The South STF at $34-34.5^{\circ} \mathrm{S}$ was narrow and sharp, with SSS dropping from 34.9 to 34.1 over a short distance. Tsuchiya and Talley (1998) interpreted the P19 data differently: They placed the STF between $33^{\circ} \mathrm{S}$ and $37^{\circ} \mathrm{S}$, apparently largely based on nutrient data. Indeed, the nutrients rose sharply south of approximately $35^{\circ} \mathrm{S}$. Notably, Tsuchiya and Talley (1998) recognized the multi-frontal structure of the STF by calling it "the banded zone" (ibid., p. 12,906). North of the North STF, the STMW (SPESTMW according to Wong and Johnson, 2003) $17^{\circ} \mathrm{C}$ thermostad is $2^{\circ} \mathrm{C}$ colder than that along $103^{\circ} \mathrm{W}\left(17^{\circ} \mathrm{C}\right.$ vs. $19^{\circ} \mathrm{C}$, respectively), becoming warming farther north $\left(18^{\circ} \mathrm{C}\right.$ vs. $20^{\circ} \mathrm{C}$, respectively). The SSS range across the $29^{\circ} \mathrm{S}-$ 
-9 -

$37.5^{\circ} \mathrm{S}$ belt exceeds $1.7 \mathrm{psu}$, from $<34.0 \mathrm{psu}$ at $37.5^{\circ} \mathrm{S}$ to $>35.7 \mathrm{psu}$ at $29^{\circ} \mathrm{S}$ (Koshlyakov and Tarakanov, 2005, Fig. 4). The extremely large SSS range across the STFZ along $88^{\circ} \mathrm{W}$ is accounted for by the STFZ being the northern boundary of a vast wedge-shaped area of low salinity west of Chile (McGinnis, 1974; Deacon, 1977; Neshyba and Fonseca, 1980; Uribe et al., 1982; Dávila et al., 2002; Karstensen, 2004; Saldías et al., 2019); this feature is discussed in Section 8 "Southeast Pacific." Despite the extremely large cross-frontal range of SSS, the STFZ is relatively shallow at $88^{\circ} \mathrm{W}$, extending vertically to just $300 \mathrm{~m}$ vs. $500 \mathrm{~m}$ at $150^{\circ} 30^{\prime} \mathrm{W}$.

\section{South Atlantic}

Stramma and Peterson (1990) described the South Atlantic Current, which in some places is collocated with the STF. They pointed out the nearly complete density compensation of the STF, hence a lack of geostrophic current along the STF. Meanwhile, Belkin (1993) mapped the South Atlantic STF from a set of meridional oceanographic sections. Instead of a single front, Belkin found two fronts (called the North and South STF) extending zonally parallel to one another, 400to-600 km apart, across the entire South Atlantic along approximately $34-36^{\circ} \mathrm{S}$ and $40-42^{\circ} \mathrm{S}$, respectively.

The double-front (or multi-core) structure of the South Atlantic STFZ has been confirmed from meridional oceanographic sections (Lutjeharms et al., 1993; Tsuchiya, Talley, and McCartney, 1994; Smythe-Wright et al., 1998), satellite SST data (Burls and Reason, 2006), numerical models (Juliano and Alves, 2007), satellite SSH data (Dencausse et al., 2011), and Argo float data (Rusciano et al., 2012).

The double-front structure of the STF could be gleaned from Krümmel's analysis of measurements from $>100$ sailing vessels and a handful of steamers ( $>120$ vessels combined) in the mid-19th century. Indeed, Krümmel (1882) pointedly provided two separate tables with surface water temperature data across the major (southern) front of the Brazil Current around $45^{\circ} \mathrm{S}$ and what he called "secondary" front ("Sekundäre Temperatur - Aenderung") around $40^{\circ} \mathrm{S}$ (Krümmel, 1882, Tables II and III, respectively). We can only hypothesize that Krümmel has realized the double-front nature of the Brazil Current Front yet stopped short from making such a statement in his report.

The fate of the NSTF and SSTF in the SE Atlantic is different. While the SSTF shifts poleward by $100-200 \mathrm{~km}$ and slips south of Africa into the SW Indian Ocean, the NSTF hits the continental slope of the SW Africa and retroflects. Thus, the NSTF is interrupted by the African Continent. In the South Indian Ocean, Belkin and Gordon (1996) discovered a front with temperature and salinity signatures similar to those of the South Atlantic NSTF. Given the similarity of these two fronts, Belkin and Gordon (1996) called the newly identified front the North STF and tracked it across the entire South Indian Ocean up to Australia, where it merges with the South STF to form a single STF that extends south of Australia (see next section).

The mean TS-ranges of the North STF in the SE Atlantic $\left(0-11.5^{\circ} \mathrm{E}\right)$ and South STF in the SE Atlantic and south of Africa $\left(0-40^{\circ} \mathrm{E}\right)$ determined by Belkin and Gordon (1996, Tables 7 and 8 ) are reproduced below (Table 2 ):

Table 2. Mean TS ranges (south-north) of the North STF $\left(0-11.5^{\circ} \mathrm{E}\right)$ and South STF $\left(0-40^{\circ} \mathrm{E}\right)$ after Belkin and Gordon (1996, Tables 7 and 8) 
$-10-$

\begin{tabular}{|l|l|l|l|l|}
\hline \multirow{2}{*}{ Depth, $\mathrm{m}$} & \multicolumn{2}{|c|}{ North STF } & \multicolumn{2}{c|}{ South STF } \\
\cline { 2 - 5 } & $\mathrm{T},{ }^{\circ} \mathrm{C}$ & $\mathrm{S}, \mathrm{psu}$ & $\mathrm{T},{ }^{\circ} \mathrm{C}$ & $\mathrm{S}, \mathrm{psu}$ \\
\hline 0 & $14.0-16.9$ & $34.87-35.58$ & $10.3-15.1$ & $34.30-35.18$ \\
\hline 200 & $12.1-15.3$ & $34.99-35.42$ & $8.0-11.3$ & $34.42-34.92$ \\
\hline 400 & $9.3-12.2$ & $34.71-35.07$ & $6.1-8.6$ & $34.38-34.63$ \\
\hline 600 & $6.0-9.2$ & $34.40-34.73$ & $4.2-5.9$ & $34.30-34.44$ \\
\hline
\end{tabular}

\section{South Indian Ocean}

The South STF in the South Indian Ocean is a continuation of the South STF in the South Atlantic and therefore inherits the latter's characteristics (Belkin and Gordon, 1996). While being squeezed between the Agulhas Front and Subantarctic Front, the SSTF does not merge with either front, despite its proximity to both fronts. The SSTF thus retains its identity up to the central part of the South Indian Ocean, north of the Kerguelen Plateau, where it peels off toward SW Australia, where it merges with the North STF to form a single STF that continues eastward south of Australia along $40^{\circ} \mathrm{S}$ toward Tasmania.

The North STF was the last major front discovered in the Southern Ocean (Belkin and Gordon, 1996). This front is poorly defined in the SW Indian Ocean yet well defined in the central and eastern parts of the South Indian Ocean (Belkin and Gordon, 1996). In the central South Indian Ocean, the North STF comes up to $31^{\circ} \mathrm{S}-32^{\circ} \mathrm{S}$, then comes down to $34^{\circ} \mathrm{S}-35^{\circ} \mathrm{S}$ off Perth (Freemantle) before it merges with the SSTF to form a "classical" single STF south of Cape Leeuwin.

The North STF is defined as the northern boundary of the Subtropical Mode Water and at the same time the southern boundary of the subtropical high-salinity pool, with surface salinity exceeding 35.7 in the center of the pool. From two meridional sections in Belkin and Gordon (1996, Figs. 13-14), the North STF is best defined at $100 \mathrm{~m}$, where the front's southern edge had $\mathrm{T}=15-16^{\circ} \mathrm{C}, \mathrm{S}=35.5$ along $65^{\circ} \mathrm{E}$ in July 1976 (ibid., Fig. 13) and $\mathrm{T}=14^{\circ} \mathrm{C}, \mathrm{S}=35.4$ along $70^{\circ} \mathrm{E}$ in November 1970 (ibid., Fig. 14). The North STF is a strong salinity front, with surface salinity crossfrontal step of about $0.5 \mathrm{psu}$, and a moderate temperature front, with surface temperature crossfrontal step of about $2^{\circ} \mathrm{C}$ to $3^{\circ} \mathrm{C}$.

The double-front structure of the STFZ in the South Indian Ocean established by Belkin and Gordon (1996) has been confirmed from continuously sampled surface temperature and salinity data by Holliday and Read (1998), from meridional oceanographic sections by Anilkumar et al. (2006), He et al. (2006), and Luis and Sudhakar (2009), among others, and from satellite SST data by Kostianoy et al. (2004).

The path and structure of the STF south of Australia are still debated. According to Belkin and Gordon (1996), the North and South STF merge west of $120^{\circ} \mathrm{E}$ and south of Cape Leeuwin, at about $40^{\circ} \mathrm{S}$ to form a single "classical" STF that continues eastward along $40^{\circ} \mathrm{S}$, then southeastward to pass south of Tasmania (at about $45-46^{\circ} \mathrm{S}$ ) yet north of the South Tasman Rise. This path is consistent with the Deacon (1982) circumpolar path of the STF determined as the location where surface salinity rises above 34.9, "usually within a sharp rise from approximately 34.6 to 35.1..." (ibid., p. 5). The STF's passage between Tasmania and the South Tasman Rise has been confirmed by Sokolov and Rintoul (2002) from numerous transects south of Tasmania. 
The above canonical view of the STF south of Australia was disputed by James et al. (2002), who conducted a high-resolution survey of the STF south of Australia in summer and winter of 1998, using a towed CTD system (SeaSoar), to conclude (ibid., p. 146):

"During winter, the STF south of Australia is located near $38-39^{\circ} \mathrm{S}$. It is not continuous between the Indian and Pacific Oceans but encounters strong westward flow south of Tasmania. It ends at the continental shelf west of Bass Strait near $40^{\circ} \mathrm{S}$... During summer, the temperature expression of the STF is covered by a 50-70-m-thick mixed layer... Its salinity expression extends through the mixed layer to the surface. The location of the STF does not change much during the year - the data from the summer voyage show that it is found at $38-39^{\circ} \mathrm{S}$ and produces large filaments as it approaches Bass Strait. These filaments can push southward beyond $40^{\circ} \mathrm{S} \ldots$ it is not possible to categorically rule out STF continuity."

From satellite SST data, Kostianoy et al. (2004) determined that the North and South STF do not merge south of Cape Leeuwin but continue separately eastward up to Tasmania, where the North STF ceases short of the western entrance to the Bass Strait, while the South STF extends eastward via the South Tasman Saddle between Tasmania and South Tasman Rise. Their Fig. 9 presents a map of SST gradients from mid-July 1999 that reveals two SST fronts south of SW Australia, interpreted by Kostianoy et al. (2004) as the North and South STF. In the absence of other data that would corroborate this important result, the above conclusion still needs validation. Meanwhile, by interpreting the WOCE S05 section along $120^{\circ} \mathrm{E}$ (Nov-Dec 1994), He et al. (2006) stated that this section has crossed two different fronts that they identified with the North and South STF. However, a careful inspection of their Fig. 2 makes clear that this section has crossed a single front and a southward meander (or a warm ring) of the same front.

Density compensation across the STF was addressed by Stramma (1992) and revisited in detail by James et al. (2002) and Tippins and Tomczak (2003). From high-resolution towed CTD data in summer and winter 1998, James et al. (2002) found (ibid., p. 129):

"During both seasons, the STF is characterized by moderate to strong density compensation with the horizontal density ratio $\left(\mathrm{R}_{\rho}=\alpha \Delta \mathrm{T} / \beta \Delta \mathrm{S}\right)$ close to 1 both in and below the mixed layer. This contrasts with observations in other regions where $\mathrm{R}_{\rho}$ tends towards 2 below the mixed layer."

The density compensation of the STF is the reason why the South Indian Ocean Current (SIOC) identified by Stramma (1992) deviates from the STF in the SE Indian Ocean, east of $90^{\circ} \mathrm{E}$, and continues NE toward Western Australia (ibid., Fig. 5). The SIOC thus closes the anticyclonic circulation of the subtropical gyre of the South Indian Ocean (addressed in more detail by Stramma and Lutjeharms, 1997) similar to the anticyclonic subtropical gyre of the South Atlantic (Stramma and Peterson, 1990; Peterson and Stramma, 1991).

Regarding the STF continuity from the South Indian Ocean into the SW Pacific, Stramma (1992, p. 429) noted: "It is unlikely that the subtropical water from the SIOC flows rather eastward south of Australia, as Tasmania builds up a barrier for the flow." Combined with the anticyclonic circulation of the SIOC west of Australia, the above reasoning led Stramma (1992) to conclude that (ibid., p. 429) "a permanent flow of the water of the SIOC south of Australia is unlikely, and most of the subtropical water of the Indian Ocean recirculates in the Indian Ocean."

Circulation around Tasmania is rather complicated, with two southward currents meeting south of Tasmania being out of phase with one another: The East Australian Current off the east 
coast is strongest in summer, while the Zeehan Current off the west coast is strongest in winter (Ridgway, 2007). This complex pattern of two opposing and interacting currents complicates the identification of the STF south of Tasmania. The circulation pattern becomes even more complicated due to sporadic outflows of the East Australian Current's southern extension into the SE Indian Ocean via the South Tasman Saddle south of Tasmania dubbed the "Tasman Leakage" (Oke et al., 2019a).

\section{Tasman Sea}

Before discussing the STF in the Tasman Sea, a terminological note is needed. The "classical" STF distinguished south of Australia long ago (e.g., Deacon, 1937) crosses the southern Tasman Sea as the South STF, whereas the North STF crosses the northern Tasman Sea (Jeffrey, 1986). The South STF has a double-front structure, with the major southern branch $\left(43-46^{\circ} \mathrm{S}\right)$ and minor northern branch $\left(40-43^{\circ} \mathrm{S}\right)$ identified with elevated salinity gradients in the 34.7-35.1 and 35.135.4 range, respectively (Jeffrey, 1986; Stanton and Ridgway, 1988; Hamilton, 2006). The southern branch of the South STF extends from Tasmania eastward across the southern Tasman Sea along $44-46^{\circ} \mathrm{S}$ to the south of New Zealand (Jeffrey, 1986; Stanton and Ridgway, 1988; Szymanska and Tomczak, 1994; Tilburg et al., 2001; Hamilton, 2006; Behrens et al., 2021) and continues as the Southland Front (Butler et al., 1992; Shaw and Vennell, 2001; Tilburg et al., 2001; Sutton, 2003; Hopkins, 2008; Hopkins et al., 2010; Smith et al., 2013; Smith, 2017; Behrens et al., 2021).

In the northern Tasman Sea, the East Australian Current branches eastward as the Tasman Front (Denham and Crook, 1976; Stanton, 1979; Andrews et al., 1980; Stanton, 1981; Tilburg et al., 2001; Ridgway and Dunn, 2003; Oke et al., 2019a, 2019b) or the North STF because the Tasman Front is the most upstream segment of the North STF in the SW Pacific. From an XBT survey, Denham and Crook (1976) identified a subsurface thermal front, termed it the Tasman Front, and suggested that it originates as a zonal extension of the East Australian Current. From ship and air surveys, Andrews et al. (1980, p. 1854) determined that "After separation from the continental slope, the East Australian Current feeds into the conjunction of the warm South Coral and cool Tasman Seas. This conjunction is seen as an abrupt change of temperature at all depths peaking at $\sim 6^{\circ} \mathrm{C}$ between 150 and $300 \mathrm{~m}$ depth." Based on a detailed XBT survey, Stanton (1981, p. 289) concluded: "The front marked a coherent, meandering, zonal jet which crosses the Tasman Sea and hence links at least part of the East Australian Current to the other western boundary currents in the subtropical gyre. The frontal meandering derives from both the variability of the East Australian Current system and the topographic effects of the major ridge systems in the north Tasman Sea. The front is less distinct over the crests of these ridges."

After crossing the Tasman Sea to the north of New Zealand, the Tasman Front continues as the East Auckland Current and its extension, the East Cape Current, then feeds the North STF along the northern flank of the Chatham Rise (Jeffrey, 1986; Belkin, 1988; Belkin and Gordon, 1996; Sutton, 2001; Smith, 2017).

Belkin and Cornillon (2003) mapped SST fronts from Pathfinder AVHRR 9-km data (19851996). Their frontal frequency maps revealed a well-defined bifurcation of the North STF (Tasman Front) west of the North Island, New Zealand. The northern branch of the Tasman Front continues toward the north of the North Island, then skirts the east coast of the North Island and eventually aligns with the northern flank of the Chatham Rise. The southern branch of the 
Tasman Front extends toward the Cook Strait. The locations of both branches of the Tasman Front are controlled by bathymetry, particularly by the Challenger Plateau wedged between the branches (Tilburg et al., 2001; Tilburg et al., 2002; Belkin and Cornillon, 2003). The pattern of SST fronts documented by Belkin and Cornillon (2003) is qualitatively different from the current schematic by Ridgway and Dunn (2003, Fig. 7) based on a numerical modeling study. This radical discrepancy warrants a special investigation.

\section{New Zealand sector}

Immediately east of New Zealand, the North and South STF are associated with coastal currents. This is the only place in the World Ocean where a subtropical front is linked to a coastal current. The North STF is associated with the East Auckland Current and its extension, the East Cape Current. These currents flow south along the east coast of the North Island to the Chatham Rise, where the North STF aligns with the northern flank of the Chatham Rise. The South STF is associated with the Southland Current flowing NE along the east coast of the South Island, then eastward along the southern flank of the Chatham Rise.

The above schematic description is a simplification of the rather complicated circulation over the New Zealand shelves (Chiswell et al., 2015; Durante et al., 2021; Stevens et al., 2021; de Souza et al., 2021). Most importantly, the coastal circulations east of the North and South Island are not isolated from one another. Instead, the Southland Current branches into the Merno Saddle to connect to the East Auckland Current (Chiswell et al., 2015; Durante et al., 2021; Stevens et al., 2021). Since the Southland Current carries a substantial amount of subantarctic water (Sutton, 2003), the NSTF receives an influx of subantarctic water via the Merno Saddle. This is the only place in the Southern Ocean, where the North STF is directly affected by subantarctic waters.

The double-front STFZ in the SW Pacific Ocean was discovered during the R/V Dmitriy Mendeleyev Cruise 34 in 1984-1985 (Belkin, 1988; Belkin, Gritsenko, and Kryukov, 1988; Belkin, Gusev, and Levin, 1988). The existence of the double-front STFZ over the Chatham Rise was confirmed by Sutton (2001), who used meridional sections with closely spaced CTD casts that resolved the North and South STF. Using a 3D hydrodynamic model (ROMS), Hadfield et al. (2007) reproduced the double-front STFZ over the Chatham Rise. The fate of the STFZ east of the Chatham Islands remains debatable. According to Belkin (1988), both North and South STF continue ENE and then extend zonally along approximately $35^{\circ} \mathrm{S}$ and $40^{\circ} \mathrm{S}$, respectively. However, as early as 1981, Ronald Heath documented the STF veering south after leaving the southern flank of the Chatham Rise (Heath, 1981). The same southward bend of the STF was found in a satellite SST climatology by Uddstrom and Oien (1999), reproduced in numerical modeling studies by Tilburg et al. (2001) and Tilburg et al. (2002), and found in a satellite altimetry study by Fernandez et al. (2014) (see also a comprehensive review by Chiswell et al., 2015). In a global analysis of satellite altimetry data, Graham and de Boer (2013) identified the Dynamic STF in the Southern Ocean and concluded that after passing along the Chatham Rise the Dynamic STF shifts south to merge with the SAF. From 20 years (1992-2012) of satellite altimetry data, Fernandez et al. (2014) confirmed the southward excursion of the Dynamic STF south of the Chatham Rise to the point of confluence with the SAF east of the Bounty Plateau and north of the Bollons Seamount (near $51^{\circ} \mathrm{S}, 176^{\circ} \mathrm{W}$ ). The confluence remained stable, apparently controlled by the local bathymetry (Bollons Seamount), while the front created by the STF-SAF merger grew 
stronger in SSH and SST over time. The cross-frontal SST step was computed by averaging SST in two widely separated areas that were supposed to characterize subtropical and subantarctic waters (STW and SAW, respectively) located between $38-46^{\circ} \mathrm{S}$ for STW and $52-60^{\circ} \mathrm{S}$ for SAW (dashed boxes $\mathbf{b}$ and $\mathbf{c}$, respectively, in their Fig. 1). The choice of the SAW box $\mathbf{c}$ is reasonable since this area is located between the SAF and Polar Front (Orsi et al., 1995; Belkin and Gordon, 1996). The annual mean SST in this box varied between $5.3-6.5^{\circ} \mathrm{C}$ (Fernandez et al., 2014, Fig. 8, bottom), which is typical of the SAW (e.g., Stevens et al., 2021). However, the choice of the STW box a cannot be justified. Indeed, the annual mean SST in this box varied between $13-15^{\circ} \mathrm{C}$ (ibid., Fig. 8, top), which is typical of the northern subantarctic waters south of the STFZ (Belkin, 1988) and not typical of subtropical waters that are much warmer (e.g., Stevens et al., 2021).

The quasi-zonal pattern of the STFZ extending ENE past the Chatham Islands (Belkin, 1988; Belkin and Gordon, 1996) has been confirmed by Behrens et al. (2021) who studied the spatial and interannual variability of the STF using a multi-decadal eddy-resolving ocean hindcast model and Argo data. The STF was defined as a water mass boundary by the southernmost location of the $11^{\circ} \mathrm{C}$ isotherm and $34.8 \mathrm{psu}$ isohaline between 100 and $500 \mathrm{~m}$. Remarkably consistent with one another, both the model and Argo data revealed the STF rebounding northward after the southward dip south of the Chatham Islands (ibid., Fig. 8). The northward rebound is much better defined in salinity vs. temperature, which is hardly accidental because the STF is always better defined in salinity vs. temperature. After the rebound, the STF continues northeast to cross over the Louisville Seamount Chain at $40.5^{\circ} \mathrm{S}, 166^{\circ} \mathrm{W}$ (ibid., Fig. 8) - almost precisely where the North STF was found along a dedicated oceanographic transect (see the next paragraph) during the R/V Dmitry Mendeleyev Cruise 34 (Belkin, 1988).

The STFZ's path and structure between New Zealand and $126^{\circ} \mathrm{W}$ were documented during the R/V Dmitriy Mendeleyev Cruise 34 from three meridional CTD sections and a series of crisscrossing transects in all directions during which underway SST and SSS data were acquired continuously by two independent flow-through thermosalinographs (TSG) along with samples of nutrients from the surface layer (Belkin, 1988; Belkin, Gritsenko, and Kryukov, 1988; Belkin, Gusev, and Levin, 1988; Vinogradov and Flint, 1988). The North STF was located owing to a dedicated transect along the Louisville Seamount Chain specifically designed to precisely determine which passage between numerous seamounts is used by the North STF to cross over this mountain chain. The transect was executed on 2 January 1985. The underway SST and SSS data acquired during this transect allowed the North STF to be detected in real time, after which two CTD stations were made on the opposite sides of the North STF that confirmed the underway data. The North STF was found at $40.0^{\circ} \mathrm{S}, 166.0^{\circ} \mathrm{W}$, leaning against the northwest slope of the Ghost Seamount located at $40.70^{\circ} \mathrm{S}, 165.35^{\circ} \mathrm{W}$, rising from $4500 \mathrm{~m}$ to $620 \mathrm{~m}$ depth (Rowden et al., 2017, Table 1). Across the front, SSS changed from 34.56 to 34.92, while SST changed from $19.00^{\circ} \mathrm{C}$ to $19.56^{\circ} \mathrm{C}$ (Belkin, Gusev, and Levin, 1988).

\section{Central South Pacific}

The STFZ is well observed in the SW Pacific, between Tasmania and the Chatham Islands. By contrast, very few oceanographic expeditions explored the STFZ east of the Chatham Islands, across the Central South Pacific, up to the SE Pacific, where the STFZ was systematically studied by Chilean scientists (Chaigneau and Pizarro, 2005a, 2005b, 2005c). The extreme remoteness of 
the Central South Pacific makes any oceanographic expedition prohibitive. As a result, the subtropical and subantarctic zones of the Central South Pacific are the least studied areas of the World Ocean. In the west, the spatial density of CTD data drops off precipitously east of the Chatham Islands (east of $175^{\circ} \mathrm{W}$ ). In the east, the CTD data density drops off west of $100^{\circ} \mathrm{W}$ $110^{\circ} \mathrm{W}$. Thus, the vast area between $175^{\circ} \mathrm{W}$ and $110^{\circ} \mathrm{W}$ is data poor. The western and central parts of this area, between New Zealand and $126^{\circ} \mathrm{W}$, were covered by a large-scale oceanographic survey during the R/V Dmitriy Mendeleyev Cruise 34 (Belkin, 1988; Belkin, Gritsenko, and Kryukov, 1988; Belkin, Gusev, and Levin, 1988; Vinogradov and Flint, 1988) described in the previous section. This survey conducted in early 1985 remains the only dedicated multi-disciplinary oceanographic study of the Central South Pacific to date. The paucity of research-quality data on the STFZ is partly mitigated by Argo floats and oceanographic data collected by fisheries oceanographers and fishers after the discovery of the last remaining superstock of pelagic fish, namely Chilean jack mackerel Trachurus murphyi (see Section 9).

Given the paucity of in situ observations, particularly the acute shortage of meridional sections across the quasi-zonal STFZ, most authors use long-term average distributions of SSS and fixed salinity criteria to map the STF in the Southern Ocean. For example, Deacon (1982, Fig. 1)) mapped the STF using the SSS $=34.9$ isohaline as a proxy for the STF axis, while noting that the SSS typically ranges across the STF from 34.6 to 35.1. Orsi et al. (1995, Fig. 4) mapped the STF at $100 \mathrm{~m}$ depth as a band (not a line as did Deacon) across which temperature changes from $10^{\circ} \mathrm{C}$ to $12^{\circ} \mathrm{C}$, while salinity changes from 34.6 to 35.0 , respectively.

The fallacy of fixed criteria was emphasized by Belkin and Gordon (1996), who used a radically different approach by adjusting their quantitative (numerical) frontal criteria downstream, while retaining qualitative (structural) criteria. This approach allowed Belkin and Gordon (1996) to track all major fronts of the Southern Ocean across the 150-degree longitudinal span from the Greenwich Meridian $\left(0^{\circ} \mathrm{E}\right)$ to Tasmania $\left(150^{\circ} \mathrm{E}\right)$. Farther east, in the South Pacific, Koshlyakov and Tarakanov (2005) used the same approach as did Belkin and Gordon (1996) by adjusting salinity criteria downstream. The location of the STF as a water mass boundary between the surface subantarctic water (SASW) and surface subtropical water (STSW) was identified by Koshlyakov and Tarakanov (2005) with the axis of a quasi-zonal band of increased meridional gradient of SSS. The meridional (south-north) SSS range across the maximum gradient band varied substantially from west to east across the South Pacific: $34.7-35.0$ west of $155^{\circ} \mathrm{W}, 34.4-$ 35.0 between $155^{\circ} \mathrm{W}-105^{\circ} \mathrm{W}$, and $34.1-34.8$ east of $105^{\circ} \mathrm{W}$. The above-cited downstream adjustment of salinity criteria is done largely at the expense of the southern boundary (from 34.7 to 34.4 to 34.1 ), while the northern boundary salinity criterion is more stable, changing from 35.0 to 34.8 across the entire South Pacific. The freshening of the southern boundary is caused by the wedge-shaped low-salinity water mass extending westward from Chile and discussed in detail below. The STF path mapped by Koshlyakov and Tarakanov (2005, Fig. 6) using the downstreamadjusted salinity criteria is largely consistent with the STF paths in Deacon (1982), Stramma et al. (1995), and Orsi et al. (1995) yet different from the STFZ in Belkin (1988) and Belkin and Gordon (1996). The main difference is the absence of the North STF in the Koshlyakov and Tarakanov (2005) map. Otherwise, their STF is largely congruent with the South STF in Belkin (1988) and Belkin and Gordon (1996) except for the general east-northeast trend of the STF across the entire South Pacific in the Koshlyakov and Tarakanov (2005) map, which is consistent with Deacon (1982), Stramma et al. (1995), and Orsi et al. (1995) and only consistent with Belkin (1988) and 
Belkin and Gordon (1996) in the SW Pacific, where the latter's STFZ also trends ENE. Our present results based on the WOCE data (Section 2) point to the ENE trend across the entire South Pacific, thus being consistent with the ENE trend obtained by other researchers cited above.

\section{Southeast Pacific}

The SE Pacific has a much better data coverage than the Central South Pacific. This coverage includes the WOCE sections P18 along $103^{\circ} \mathrm{W}$ and P19 along $88^{\circ} \mathrm{W}$ (Tsuchiya and Talley, 1998). The western periphery of the SE Pacific was crossed by the WOCE section P17 along $135^{\circ} \mathrm{W}$ (Tsuchiya and Talley, 1996). The subtropical-subantarctic segments of these sections were also analyzed - and the STF discussed - by Wong and Johnson (2003) and Koshlyakov and Tarakanov (2005).

A climatology of the mean surface circulation and fronts in the SE Pacific was produced by Chaigneau and Pizarro (2005b, 2005c). Their results regarding the STF are consistent with those obtained by previous researchers (Deacon, 1982; Stramma et al., 1995; Orsi et al., 1995; Schneider et al., 2003) and those based on the above-mentioned WOCE sections (Tsuchiya and Talley, 1996, 1998; Koshlyakov and Tarakanov, 2005; our analysis in Section 2).

To complement the oceanographic description of the SE Pacific, Chaigneau and Pizarro (2005a) studied a local population of mesoscale eddies that provide an alternative mechanism of westward transport of passive plankters (e.g., fish larvae) against the dominant eastward transport along the STFZ; this issue is discussed in the next section. The westward propagation of mesoscale eddies in the World Ocean is a global phenomenon (Chelton et al., 2011). In the SE Pacific, such eddies emanated from the Chile-Peru Current propagate with a mean speed of 3 $\mathrm{cm} / \mathrm{s}$ near the STFZ zonal belt (Chaigneau and Pizarro, 2005a). Belmadani et al. (2017) used an eddy-resolving numerical ocean model and automated eddy tracking algorithms to show that such eddies are primarily generated in the STF $\left(35^{\circ} \mathrm{S}-40^{\circ} \mathrm{S}\right)$. These eddies are coherent vortices, not Rossby waves. They have typical swirls velocities $S$ of $\sim 10 \mathrm{~cm} / \mathrm{s}$ and drift velocities $D$ of $\sim 3$ $\mathrm{cm} / \mathrm{s}$, thus having the nonlinearity parameter S/D of 3-4, which is indicative of highly nonlinear eddies (Chelton et al., 2011). As emphasized by Chelton et al. (ibid., p. 169):

"The distinction between linear Rossby waves and nonlinear eddies is important since the latter can transport water parcels and their associated physical, chemical and biological properties, while linear Rossby waves cannot. Eddies can thus have important influences on heat and momentum fluxes and on marine ecosystem dynamics."

\section{South Pacific STFZ and the ecology of Chilean jack mackerel}

The most remote segment of the STFZ crosses the Central South Pacific, which is the least studied region of the World Ocean. The extreme remoteness of this area challenged sea-going oceanographers before the advent of satellite oceanography. Meanwhile, this region became a major fishing ground after a huge stock of Chilean jack mackerel Trachurus murphyi was discovered in the 1970s. Catches of jack mackerel reached $5 \mathrm{Mt}$ by 1995 - a huge number given the total global fish catch of $70 \mathrm{Mt}$ at the time. Clearly, the $5 \mathrm{Mt} /$ year catch was unsustainable, and the jack mackerel fishery collapsed quickly, with the collapse being exacerbated by complex interactions between fishing, climate, and stock dynamics (Lima et al., 2020). Now the jack 
mackerel fishery is tightly regulated. Once fully recovered, the jack mackerel fishery will become one of the most important sustainable deep-blue fisheries in the World Ocean.

In the South Pacific, the outstanding role of the STFZ in the ecology of Trachurus murphyi was recognized early on. Based on the collections of T. murphyi larvae made off Peru in 1982 and in the central South Pacific in 1985, Evseenko (1987) pointed out that the spawning area of jack mackerel in the open ocean is confined to the "Subtropical Convergence Zone" (STCZ, the term replaced here by STFZ). The open ocean larvae analyzed by Evseenko (1987) were collected during the same cruise when the STFZ was mapped between New Zealand and $126^{\circ} \mathrm{W}$ (R/V Dmitriy Mendeleyev Cruise 34; Belkin, 1988; Vinogradov and Flint, 1988). Evseenko put the larvae distribution into an oceanographic context by adding to the larvae map the extreme seasonal locations of the $16^{\circ} \mathrm{C}$ isotherm in winter (August) and summer (March) (ibid., Fig. 4). Assuming (reasonably) that the larvae caught at $139^{\circ} \mathrm{W}$ were brought from the west by an eastward current along the STFZ, which was a consensus opinion at the time, Evseenko concluded that the spawning area extends westward up to $150-160^{\circ} \mathrm{W}$. Regarding the population structure of jack mackerel, Evseenko (1987) considered three hypotheses: (1) single population, (2) separate inshore and offshore populations, and (3) offshore population dependent on the inshore population; then settled at the $3^{\text {rd }}$ hypothesis by eliminating the first two. The population structure of jack mackerel in the South Pacific remained a hotly debated topic ever since (Serra, 1991; Taylor, 2002; Cárdenas et al., 2009; Ashford et al., 2011; Gerlotto et al., 2012; Vásquez et al., 2013; Zhu et al., 2014; Dragon et al., 2017; Parada et al., 2017).

The main conclusion by Evseenko (1987) about the jack mackerel spawning within the STCZ was confirmed with a much larger data set by Bailey (1989) who noted (ibid., p. 273): "The predominance of $T$. murphyi in the diet of albacore suggests that the jack mackerel are abundant between latitudes $34^{\circ} \mathrm{S}$ and $41^{\circ} \mathrm{S}$, longitudes $127^{\circ} \mathrm{W}$ and $165^{\circ} \mathrm{W}$ during the austral summer." Bailey (1987) extended the jack mackerel spawning area westward up to the Chatham Rise, presented evidence of the transpacific distribution of jack mackerel along the Subtropical Convergence Zone, and concluded (ibid., p. 277): "It is apparent that Trachurus murphyi is found and likely spawn across the South Pacific from New Zealand to Chile." The strong spatial correlation between the Subtropical Front (Convergence) and jack mackerel spawning/nursing grounds has been confirmed in numerous studies (Núñez et al., 2004; Cubillos et al., 2008; Núñez et al., 2010; Vásquez et al., 2013). Thus, the concept of the transpacific migrations of jack mackerel along the Subtropical Convergence Zone has been widely accepted (Serra, 1991; Elizarov et al., 1993; Taylor, 2002), with Elizarov et al. (1993) coining the term "jack mackerel belt" to describe the distribution of T. murphyi across the South Pacific.

Despite the common recognition of the important role played by the STFZ in the ecology of jack mackerel, very few field studies to date included oceanographic surveys of the STFZ. Instead, most studies resorted to fishery-dependent data from commercial fisheries augmented by remote sensing data such as SST, SSH, and CHL (e.g., Bertrand et al., 2016; Li et al., 2016; Parada et al., 2017). Numerous studies focused on temperature ranges preferred by $T$. murphyi during different life stages, often using SST and certain temperature indices as proxies. There is a consensus regarding $T$. murphyi spawning at relatively high temperatures typical of the STFZ. Juveniles remain in or near the STFZ, where they feed mostly on small prey. Adult fish spend most time in colder waters typical of the northern part of the subantarctic zone, south of the STFZ, down to $45-46^{\circ} \mathrm{S}$ in the SE Pacific, where they feed on larger prey. 
The spawning grounds of jack mackerel are associated with a narrow SST range of $16-18^{\circ} \mathrm{C}$ typical of the STFZ (Cubillos et al., 2008; Dragon et al., 2017). Consistent with other works, numerous Russian studies (including earlier papers reviewed by Taylor (2002)) relate the spatial distribution of jack mackerel larvae and juveniles with SST of $15-19^{\circ} \mathrm{C}$ typical of the STFZ. Since adult fishes forage in northern subantarctic waters south of the STFZ, higher CPUEs are associated with colder SST of $12-15^{\circ} \mathrm{C}$ (Li et al., 2013). Seasonal variability of optimum SST ranges associated with highest CPUEs (based on Chinese fishery-dependent data) is documented by Li et al. (2016): Seasonal distributions of SST are approximately Gaussian (except summer), with modal SST of $13^{\circ} \mathrm{C}, 14^{\circ} \mathrm{C}$, and $15^{\circ} \mathrm{C}$ in fall, winter, and spring, respectively (ibid., Fig. 2); while the summer SST distribution is bimodal, reflecting a wide dispersion of the fishing fleet. The modal SSTs determined by Li et al. (2016) are generally consistent with the optimum SST ranges determined by Zhang et al. (2015): $13-15^{\circ} \mathrm{C}$ in autumn, $12-14^{\circ} \mathrm{C}$ in winter, $13-16^{\circ} \mathrm{C}$ in spring, and $15-19^{\circ} \mathrm{C}$ in summer. The main fishing area off central-southern Chile is usually demarcated by the $15^{\circ} \mathrm{C}$ isotherm (Arcos et al., 2001; Li et al., 2013; Li et al., 2016).

The concept of $T$. murphyi spawning and migrating along the STFZ is supported by fishing fleet distribution data. Soldat et al. (2008) presented maps showing a strong concentration of Russian fishing vessels within a narrow zonal band just a few hundred km wide within the 35$45^{\circ} \mathrm{S}$ belt; this zonal band extends from Chile westward into the Central South Pacific and is collocated with the STFZ. Distribution of Chinese fishing vessels (Li et al., 2013; Li et al., 2016) reveals a similar pattern, with the fishing fleet shifting north-south in sync with seasonal shifts of the STFZ.

The jack mackerel's length and age in the South Pacific increase westward (e.g., Horn and Maolagáin, 2020). The most obvious explanation of this trend is the westward migration of jack mackerel. The eastward South Pacific Current (approximately collocated with the STFZ) is rather sluggish, with mean surface velocities of $2 \mathrm{~cm} / \mathrm{s}$ east of $100^{\circ} \mathrm{W}$ according to Chaigneau and Pizarro (2005b) and geostrophic transport of 2 to 5 Sv (Stramma et al., 1995). Therefore, the jack mackerel could swim long distances against this current without expending too much energy fighting the opposing current. Horn and Maolagáin (2020) analyzed otoliths from T. murphyi collected off New Zealand in 2007-2019 and concluded that there were at least two invasions of jack mackerel from the high seas into the New Zealand waters. The STFZ is the most plausible path taken by the immigrant $T$. murphyi coming toward New Zealand from the east.

There are two alternative mechanisms facilitating the westward migration of jack mackerel in the South Pacific: (1) westward countercurrent (McGinnis, 1974); (2) westward propagation of mesoscale eddies (Chaigneau and Pizarro, 2005a). These mechanisms are not mutually exclusive. Instead, they are rather complementary. McGinnis (1974) mapped spatial distribution of lanternfish larvae that revealed a distinct trend of westward increase of larval age. Since the larvae are poor swimmers, they are passive tracers of ocean currents. Thus, McGinnis concluded that the larvae are carried to the west by a westward current that flows against the broad eastward West Wind Drift. Deacon (1977) supported McGinnis' hypothesis by pointing out the existence of a westward wedge of low-salinity water in the subantarctic zone west of Chile as a proof of a westward current. The low-salinity wedge originates off the Chilean coast owing to the copious amount of precipitation falling onto the western slopes of the Andes and feeding numerous rivers draining the slopes (Dávila et al., 2002; Saldías et al., 2019). For an alternative, model-based explanation of the westward wedge of low salinity see Karstensen (2004). 
The existence of a westward current was further supported by Neshyba and Fonseca (1980) and Uribe et al. (1982) who conducted an oceanographic survey based on a meridional highresolution $\left(11 \mathrm{~km}\right.$ ) XBT section along $92^{\circ} \mathrm{W}$, from $45^{\circ}$ to $35^{\circ} \mathrm{S}$, in February 1979 , and presented physical evidence of a counterflow to the eastward West Wind Drift corroborated by biological evidence based on the biogeography of phytoplankton sampled during the oceanographic survey, particularly the pennate diatom Nitzshcia longissimi, which is "generally associated with shallow coastal waters and which comprises a major fraction of the phytoplankton assemblage near the frontal zone [STFZ] but within the low-salinity tongue." (Uribe et al., 1982, p. 1229).

Another mechanism that explains the observed length/age distribution of Chilean jack mackerel across the South Pacific is the westward movement of mesoscale eddies generated off Chile (Chaigneau and Pizarro, 2005a; Belmadani et al., 2017), described in the previous section. For any marine animal (including fish) inside a mesoscale eddy in this region, traveling westward with the eddy is energetically advantageous vs. swimming against the eastward currents that dominate this region. In addition to the "free ride" inside westward-moving mesoscale eddies, fish may seek out such eddies owing to the prey concentration inside mesoscale eddies. The affinity of various marine animals, including fish, to mesoscale eddies has been documented in numerous studies reviewed most recently by Belkin (2021).

The continuous migration along the STFZ is consistent with the concept of a single population (or pelagic meta-population) of jack mackerel encompassing the entire subtropical-subantarctic belt between Chile and New Zealand (Cárdenas et al., 2009; Bertrand et al., 2016). An alternative concept envisions a few distinct populations (or sub-populations) of T. murphyi within the STFZ (Elizarov et al., 1993; Soldat et al., 2008; Ashford et al., 2011; Gerlotto et al., 2012; Dragon et al., 2017; Parada et al., 2017). From a purely oceanographic viewpoint, the multi-stock hypothesis lacks strong support. Indeed, the relatively smooth bathymetry inside this latitudinal belt could not play any substantial role in the presumed isolation of such individual stocks from one another. There are no meridional topographic barriers (steep submarine ridges or seamount chains like the Louisville Seamount Chain in the SW Pacific) that could facilitate the emergence of isolated circulation cells in the upper few hundred meters that could serve as habitats of choice for isolated populations of $T$. murphyi.

Nonetheless, seamounts in the $33-39^{\circ} \mathrm{S}, 105-120^{\circ} \mathrm{W}$ area could play a certain role in the formation of a partly isolated spawning/nursery ground (Parada et al., 2017), especially because this area is traversed by the STFZ (Belkin, 1988; Tsuchiya and Talley, 1996; Tsuchiya and Talley, 1998; Chaigneau and Pizarro, 2005c) and associated South Pacific Current (Stramma et al., 1995; Chaigneau and Pizarro, 2005b). These seamounts can impede the westward propagation of mesoscale eddies emanated from the Chile-Peru Current (Chaigneau and Pizarro, 2005a), thereby contributing to the formation of a shadow zone of eddy activity (Parada et al., 2017) favorable for the existence of an isolated population of T. murphyi.

\section{Discussion}

Circumpolar continuity of the STFZ. The circumpolar extent of the STFZ (interrupted only by South America) is confirmed by the literature survey and analysis of WOCE sections. The South STF is the "classical" STF or Subtropical Convergence (STC) identified early on (Krümmel, 1882). The South STF originates in the SW Atlantic as the southernmost eastward extension of the Brazil 
Current and continues uninterrupted across the South Atlantic towards the Agulhas Current Retroflection region. Despite close encounters and interactions with the Agulhas Current and Subantarctic Front, the South STF retains its identity across the Indian Ocean up to Tasmania (Belkin and Gordon, 1996), extends zonally across the Tasman Sea, continues as the Southland Current, and then extends zonally along the Chatham Rise. After dipping to $48^{\circ} \mathrm{S}$ south of the Chatham Islands, the South STF extends ENE across the South Pacific to end near $34^{\circ} \mathrm{S}$ east of $88^{\circ} \mathrm{W}$ (WOCE section P19) off Chile.

The North STF originates as the first eastward branch of the Brazil Current (the South STF being the second eastward branch); therefore, the North STF is traditionally called the Brazil Current Front or BCF. By combining all hydrographic data available by the early 1990s, Belkin (1993) traced the BCF (=North STF) all the way across the South Atlantic, where the North STF is interrupted by South Africa (Belkin and Gordon, 1996; Rusciano et al., 2012).

In the Indian Ocean, the North STF reconstitutes itself as a NE-ward extension of the Agulhas Current and arches across the South Indian Ocean to either merge with the South STF at 115$120^{\circ} \mathrm{E}$ (Belkin and Gordon, 1996) or continue eastward parallel to the South STF until Tasmania, where the North STF ends (Kostianoy et al., 2004).

In the northern Tasman Sea, the North STF reappears as the first eastward extension of the East Australian Current and is traditionally called the Tasman Front. Thus, the Tasman Front is a Pacific counterpart of the Brazil Current Front in the Atlantic. After crossing the Tasman Sea to the north of New Zealand, the North STF continues along the northern flank of the Chatham Rise, extends ENE to cross the Louisville Seamount Chain at $40^{\circ} \mathrm{S}, 166^{\circ} \mathrm{W}$, north of the Ghost Seamount, and then extends ENE across the South Pacific, eventually reaching $29^{\circ} \mathrm{S}$ at $88^{\circ} \mathrm{W}$ (WOCE section P19) off Chile.

STFZ and STMW. In the South Atlantic, the North STF is the southern boundary of the STMW thermostad, which is well-defined all the way from the Brazil Current eastward into the SE Atlantic. The STMW cools eastward (Table 1): from $15^{\circ} \mathrm{C}$ at $40-45^{\circ} \mathrm{W}$ (WOCE section A17), to 14$15^{\circ} \mathrm{C}$ at $35-36^{\circ} \mathrm{W}$ (WOCE section A23), to $13-14^{\circ} \mathrm{C}$ at $27-33^{\circ} \mathrm{W}$ (WOCE section A16), to $12-13^{\circ} \mathrm{C}$ at $9^{\circ} \mathrm{W}$ (WOCE section $\mathrm{A} 14$ ), and to $11-12^{\circ} \mathrm{C}$ at $2^{\circ} \mathrm{W}$ (WOCE section $\mathrm{A} 11$ ). The strong relation between STFZ and STMW is lost south of Africa, at the crossroads of ocean currents and fronts. In the SE Indian Ocean, the South STF is a boundary between STMW to the north and SAMW to the south (Belkin and Gordon, 1996). In the SE Pacific, the STFZ is the southern boundary of the South Pacific Eastern STMW (Table 1, WOCE sections P18 and P19; Wong and Johnson, 2003).

Vertical extent of STFZ varies circumpolarly. In the South Atlantic, the STFZ is extremely deep: Horizontal gradients of temperature and salinity across both North and South STF are increased well above background values in the upper $1000 \mathrm{~m}$ layer and even below. Farther east, the vertical extent of STFZ decreases down to $300 \mathrm{~m}$ in the SE Pacific. The eastward decrease of STFZ'S vertical extent might be related to the density compensation of surface waters in the SE Indian Ocean and SE Pacific documented, among others, by Stramma (1992), Stramma et al. (1995), James et al. (2002), Tippins and Tomczak (2003), Wong and Johnson (2003), and Hamilton (2006).

Fronts (gradients) in population models. The existing population models of jack mackerel include temperature among other explanatory environmental variables. None of the existing population models of jack mackerel includes fronts or gradients as proxies of fronts. At the same time, anecdotal evidence mounts of fishers actively seeking out fronts as habitats of choice for jack 
mackerel, at least during certain ontogenetic stages. For example, during the R/V Dmitry Mendeleyev Cruise 34 in 1985, surface temperature and salinity fronts in the Central South Pacific were documented continuously underway using a flow-through thermosalinograph connected to the ship's water intake (Belkin, 1988; Belkin, Gritsenko, and Kryukov, 1988; Belkin, Gusev, and Levin, 1988). The coordinates and TS-ranges of the fronts crossed by R/V Dmitry Mendeleyev were radioed daily to the nearby MV Pioner Nikolaeva (large freezer-trawler), where Dr. Nikolai Shurunov used the front data to target jack mackerel and improve the efficiency of the ship's fishing operations.

Salinity data in fish ecology. Very few, if any, population models use salinity and salinity gradient as explanatory variables. This is counterintuitive since the STF is largely a salinity front. Therefore, owing to the important ecological role of the STFZ, salinity and salinity gradients should be included into population models. The main logistical problem is the dearth of salinity data. Even when regular high-resolution XBT data are collected every 30 to $40 \mathrm{~km}$ along shipping lanes crossing the STFZ (e.g., along the Honolulu-Chile line), salinity data are collected much more infrequently by expensive XCTDs (Wong and Johnson, 2003). The data paucity problem could be solved by the development of automated flow-through thermosalinograph (TSG) systems for fishing fleets operating in the STFZ.

Front data in marine ecology and fisheries. A strong case can be made for using front data in marine ecology and fisheries. The systematic use of satellite data and state-of-the-art front detection algorithms (reviewed recently by Belkin, 2021) would have a synergetic effect. Technically and logistically, all components are available for an efficient implementation of a front-centric computerized system for jack mackerel fisheries. The most difficult aspect of such a system is taking into account qualitatively different strategies used by jack mackerel during different life stages. For example, a strong link between jack mackerel and STFZ during spawning does not exist later during nursing and foraging stages, when adult fish leaves the STFZ for colder subantarctic waters with larger prey items.

The continuity of the STFZ is discussed by Maes et al. (2018) who performed Lagrangian experiments about the long-term (1985-2013) evolution of an initially homogeneous concentration of particles on a global scale with daily horizontal currents at $1 / 4^{\circ}$ resolution. These experiments revealed a convergent pathway at the ocean surface connecting the South Indian subtropics with the South Pacific STFZ over a distance exceeding 8,000 km. Maes et al. (2018) noted that the existence of this robust and permanent pathway explains, inter alia, the rapid accumulation of anthropogenic debris in the South Pacific subtropical gyre as documented, e.g., on Henderson Island $\left(24^{\circ} 20^{\prime} \mathrm{S}, 128^{\circ} 19^{\prime} \mathrm{W}\right.$ in the Pitcairn Archipelago) (Lavers and Bond, 2017). The sharply increased concentration of debris in the South Pacific subtropical gyre was modeled and documented from in situ observations by Eriksen et al. (2013); the maximum concentration of debris observed and modeled (ibid., Fig. 1) was found immediately north of the STFZ, suggestive of debris advection by the South Pacific Current along the STFZ.

\section{Summary}

The literature survey and data analysis of the WOCE sections confirm the circumpolar continuity of the Subtropical Frontal Zone (STFZ) extending from the Brazil Current in the 
southwest Atlantic eastward into the southeast Pacific up to Chile, being bound by two fronts, North and South STF. The circumpolar continuity of the STFZ is partly interrupted by South Africa and Tasmania; in both cases, the North STF ceases, while the South STF continues eastward. The South Atlantic STFZ is the southern boundary of the well-defined STMW thermostad, which cools eastward from $15^{\circ} \mathrm{C}$ to $11^{\circ} \mathrm{C}$ between the Brazil Current and Greenwich Meridian. In the southeast Pacific, the STFZ is the southern boundary of the 17 -to- $19^{\circ} \mathrm{C}$ thermostad (South Pacific Eastern STMW). The STFZ's vertical extent is at maximum in the South Atlantic (>1000 m), decreasing to $300 \mathrm{~m}$ in the southeast Pacific off Chile. In the South Pacific, the STFZ plays a key role in the ecology of the Chilean jack mackerel Trachurus murphyi that spawn at the STFZ and migrate along the STFZ from Chile up to New Zealand.

Acknowledgments. While working on this paper, the author was supported by the Zhejiang Ocean University, Zhoushan, China.

Data Availability Statement. The data presented in this study are openly available in the World Ocean Database and WOCE Hydrographic Programme database.

\section{References}

Andrews, J.C., Lawrence, M.W., Nilsson, C.S., 1980. Observations of the Tasman Front. Journal of Physical Oceanography 10 (11), 1854-1869. https://doi.org/10.1175/15200485(1980)010<1854:0OTTF>2.0.CO;2.

Anilkumar, N., Luis, A.J., Somayajulu, Y.K., Ramesh Babu, V., Dash, M.K., Pednekar, S.M., Babu, K.N., Sudhakar, M., Pandey, P.C., 2006. Fronts, water masses and heat content variability in the Western Indian sector of the Southern Ocean during austral summer 2004. Journal of Marine Systems 63 (1-2), 20-34. https://doi.org/10.1016/j.jmarsys.2006.04.009.

Arcos, D.F., Cubillos, L.A., Núñez, S.P., 2001. The jack mackerel fishery and El Niño 1997-98 effects off Chile. Progress in Oceanography 49 (1-4), 597-617. https://doi.org/10.1016/S00796611(01)00043-X.

Ashford, J., Serra, R., Saavedra, J.C., Letelier, J., 2011. Otolith chemistry indicates large-scale connectivity in Chilean jack mackerel (Trachurus murphyi), a highly mobile species in the Southern Pacific Ocean. Fisheries Research 107 (1-3), 291-299. https://doi.org/10.1016/i.fishres.2010.11.012.

Bailey, K., 1989. Description and surface distribution of juvenile Peruvian jack mackerel, Trachurus murphyi, Nichols from the subtropical convergence zone of the central South Pacific. Fishery Bulletin 87 (2), 273-278.

Behrens, E., Hogg, A.M., England, M.H., Bostock, H., 2021. Seasonal and interannual variability of the Subtropical Front in the New Zealand region. Journal of Geophysical Research: Oceans 126 (2), e2020JC016412. https://doi.org/10.1029/2020JC016412.

Belkin, I.M., 1988. Main hydrological features of the Central South Pacific. In: Ecosystems of the Subantarctic Zone of the Pacific Ocean, edited by M.E. Vinogradov and M.V. Flint, Nauka, Moscow, pp. 21-28 (in Russian); English translation: Pacific Subantarctic Ecosystems, New Zealand Translation Centre Ltd., Wellington, 1997, pp. 12-17. http://docs.niwa.co.nz/library/public/pacific-subant-eco. 
Belkin, I.M., 1993. Frontal structure of the South Atlantic. In: Pelagic Ecosystems of the Southern Ocean [Pelagicheskie Ekosistemy Yuzhnogo Okeana], edited by N.M. Voronina. Nauka, Moscow, pp. 40-53 (in Russian; English translation available from the author).

Belkin, I.M., 2021. Remote sensing of ocean front in marine ecology and fisheries. Remote Sensing 13 (5), 883. https://doi.org/10.3390/rs13050883.

Belkin, I.M., Cornillon, P.C., 2007. Fronts in the world ocean's large marine ecosystems. ICES CM 2007/D:21, 33 pp.

Belkin, I.M., Gordon, A.L., 1996. Southern Ocean fronts from the Greenwich meridian to Tasmania. Journal of Geophysical Research: Oceans 101 (C2), 3675-3696. https://doi.org/10.1029/95JC02750.

Belkin, I.M., Cornillon, P.C., Sherman, K., 2009. Fronts in Large Marine Ecosystems. Progress in Oceanography 81 (1-4), 223-236. https://doi.org/10.1016/i.pocean.2009.04.015.

Belkin, I.M., Gritsenko, A.M., Kryukov, V.V., 1988. Thermohaline structure and hydrological fronts. In: Ecosystems of the Subantarctic Zone of the Pacific Ocean, edited by M.E. Vinogradov and M.V. Flint, Nauka, Moscow, pp. 28-36 (in Russian); English translation: Pacific Subantarctic Ecosystems, New Zealand Translation Centre Ltd., Wellington, 1997, pp. 18-23. http://docs.niwa.co.nz/library/public/pacific-subant-eco.

Belkin, I.M., Gusev, Yu.M., Levin, L.A., 1988. Surface thermohaline fronts of the South Pacific. In: Ecosystems of the Subantarctic Zone of the Pacific Ocean, edited by M.E. Vinogradov and M.V. Flint, Nauka, Moscow, pp. 36-47 (in Russian); English translation: Pacific Subantarctic Ecosystems, New Zealand Translation Centre Ltd., Wellington, 1997, pp. 24-29. http://docs.niwa.co.nz/library/public/pacific-subant-eco.

Belkin, I.M., Shan, Z., Cornillon, P., 1998. Global survey of oceanic fronts from Pathfinder SST and in situ data. Eos Transactions AGU 79 (45, Fall Meeting Supplement), F475, Abstract OS31B07.

Belmadani, A., Concha, E., Donoso, D., Chaigneau, A., Colas, F., Maximenko, N., Di Lorenzo, E., 2017. Striations and preferred eddy tracks triggered by topographic steering of the background flow in the eastern South Pacific. Journal of Geophysical Research: Oceans 122 (4), 2847-2870. https://doi.org/10.1002/2016JC012348.

Bertrand, A., Habasque, J., Hattab, T., Hintzen, N.T., Oliveros-Ramos, R., Gutiérrez, M., Demarcq, H., Gerlotto, F., 2016. 3-D habitat suitability of jack mackerel Trachurus murphyi in the Southeastern Pacific, a comprehensive study. Progress in Oceanography 146, 199-211. https://doi.org/10.1016/i.pocean.2016.07.002.

Burls, N.J., Reason, C.J.C., 2006. Sea surface temperature fronts in the midlatitude South Atlantic revealed by using microwave satellite data. Journal of Geophysical Research: Oceans 111 (C8), C08001. https://doi.org/10.1029/2005JC003133.

Butler, E.C.V., Butt, J.A., Lindstrom, E.J., Teldesley, P.C., Pickmere, S., Vincent, W.F., 1992. Oceanography of the Subtropical Convergence Zone around southern New Zealand. New Zealand Journal of Marine and Freshwater Research 26 (2), 131-154. https://doi.org/10.1080/00288330.1992.9516509.

Cárdenas, L., Silva, A.X., Magoulas, A., Cabezas, J., Poulin, E., Ojeda, F.P., 2009. Genetic population structure in the Chilean jack mackerel, Trachurus murphyi (Nichols) across the South-eastern $\begin{array}{lllll}\text { Pacific Ocean. Fisheries } 100 & \text { 12), }\end{array}$ https://doi.org/10.1016/i.fishres.2009.06.013. 
Chaigneau, A., Pizarro, O., 2005a. Eddy characteristics in the eastern South Pacific. Journal of Geophysical Research: Oceans 110 (C6), C06005. https://doi.org/10.1029/2004JC002815.

Chaigneau, A., Pizarro, O., 2005b. Mean surface circulation and mesoscale turbulent flow characteristics in the eastern South Pacific from satellite tracked drifters. Journal of Geophysical Research: Oceans 110 (C5), C05014. https://doi.org/10.1029/2004JC002628.

Chaigneau, A., Pizarro, O., 2005c. Surface circulation and fronts of the South Pacific Ocean, east of $120^{\circ} \mathrm{W}$. Geophysical Research Letters 32 (8), L08605. https://doi.org/10.1029/2004GL022070.

Chiswell, S.M., Bostock, H.C., Sutton, P.J.H., Williams, M.J.M., 2015. Physical oceanography of the deep seas around New Zealand: a review. New Zealand Journal of Marine and Freshwater Research 49 (2), 286-317. https://doi.org/10.1080/00288330.2014.992918.

Cubillos, L.A., Paramo, J., Ruiz, P., Núñez, S., Sepúlveda, A., 2008. The spatial structure of the oceanic spawning of jack mackerel (Trachurus murphyi) off central Chile (1998-2001). Fisheries Research 90 (1-3), 261-270. https://doi.org/10.1016/i.fishres.2007.10.016.

Dávila, P.M., Figueroa, D., Müller, E., 2002. Freshwater input into the coastal ocean and its relation with the salinity distribution off austral Chile $\left(35-55^{\circ} \mathrm{S}\right)$. Continental Shelf Research 22 (3), 521-534. https://doi.org/10.1016/S0278-4343(01)00072-3.

Deacon, G.E.R, 1933. A general account of the hydrology of the South Atlantic Ocean. Discovery Report 7, 171-238.

Deacon, G.E.R, 1937. The hydrology of the Southern Ocean. Discovery Report 15, 1-124.

Deacon, G.E.R., 1977. Comments on a counterclockwise circulation in the Pacific subantarctic sector of the Southern Ocean suggested by McGinnis. Deep-Sea Research 24 (10), 927-930. https://doi.org/10.1016/0146-6291(77)90561-6.

Deacon, G.E.R., 1982. Physical and biological zonation in the Southern Ocean. Deep-Sea Research 29, 1-15. https://doi.org/10.1016/0198-0149(82)90058-9.

De Boer, A.M., Graham, R.M., Thomas, M.D., Kohfeld, K.E., 2013. The control of the Southern Hemisphere Westerlies on the position of the Subtropical Front. Journal of Geophysical Research: Oceans 118 (10), 5669-5675. https://doi.org/10.1002/igrc.20407.

Dencausse, G., Arhan, M., Speich, S., 2011. Is there a continuous Subtropical Front south of Africa? Journal of Geophysical Research: Oceans 116 (C2), 02027. https://doi.org/10.1029/2010JC006587.

Denham, R.N., 1976. Tasman Front. New Zealand Journal of Marine and Freshwater Research 10 (1), 15-30. https://doi.org/10.1080/00288330.1976.9515596.

De Souza, J.M.A.C., Couto, P., Soutelino, R., Roughan, M., 2020. Evaluation of four global ocean reanalysis products for New Zealand waters-A guide for regional ocean modelling. New Zealand Journal of Marine and Freshwater Research, https://doi.org/10.1080/00288330.2020.1713179.

Dragon, A.-C., Senina, I., Hintzen, N.T., Lehodey, P., 2018. Modelling South Pacific jack mackerel spatial population dynamics and fisheries. Fisheries Oceanography 27 (2), 97-113. https://doi.org/10.1111/fog.12234.

Durante, L.M., Smith, R.O., Kolodzey, S., McMullin, R.M., Salmond, N.H., Schlieman, C.D., O'Connell-Milne, S.A., Frew, R.D., Van Hale, R., Wing, S.R., 2021. Oceanographic transport along frontal zones forms carbon, nitrogen, and oxygen isoscapes on the east coast of New 
Zealand: Implications for ecological studies. Continental Shelf Research 216, 104368. https://doi.org/10.1016/i.csr.2021.104368.

Elizarov, A.A., Grechina, A.S., Kotenev, B.N., Kuznetsov, A.N., 1993. Peruvian jack mackerel, Trachurus symmetricus murphyi in the open waters of the South Pacific. Journal of Ichthyology 33 (3), 86-104.

Eriksen, M., Maximenko, N., Thiel, M., Cummins, A., Lattin, G., Wilson, S., Hafner, J., Zellers, A., Rifman, S., 2013. Plastic pollution in the South Pacific subtropical gyre. Marine Pollution Bulletin 68 (1-2), 71-76. https://doi.org/10.1016/j.marpolbul.2012.12.021.

Evseenko, S.A., 1987. On the reproduction of the Peruvian jack mackerel, Trachurus symmetricus murphyi (Nichols), in the Southern Pacific. Journal of Ichthyology 27 (3), 151-160. Originally published in Russian in Voprosy Ikhtiologii 27 (2), 264-273.

Fernandez, D., Bowen, M., Carter, L., 2014. Intensification and variability of the confluence of subtropical and subantarctic boundary currents east of New Zealand. Journal of Geophysical Research: Oceans 119 (2), 1146-1160. https://doi.org/10.1002/2013JC009153.

Gerlotto, F., Gutiérrez, M., Bertrand, A., 2012. Insight on population structure of the Chilean jack mackerel (Trachurus murphyi). Aquatic Living Resources 25 (4), 341-355. https://doi.org/10.1051/alr/2012036.

Graham, R.M., De Boer, A.M., 2013. The Dynamical Subtropical Front. Journal of Geophysical Research: Oceans 118 (10), 5676-5685. https://doi.org/10.1002/igrc.20408.

Graham, R.M., de Boer, A.M., Heywood, K.J., Chapman, M.R., Stevens, D.P., 2012. Southern Ocean fronts: Controlled by wind or topography? Journal of Geophysical Research: Oceans 117, C08018. https://doi.org/10.1029/2012JC007887. Check! Cite!

Hadfield, M.G., Rickard, G.J., Uddstrom, M.J., 2007. A hydrodynamic model of Chatham Rise, New Zealand. New Zealand Journal of Marine and Freshwater Research 41 (2), 239-264. https://doi.org/10.1080/00288330709509912.

Hamilton, L.J., 2006. Structure of the Subtropical Front in the Tasman Sea. Deep-Sea Research Part I 53 (12), 1989-2009. https://doi.org/10.1016/i.dsr.2006.08.013.

He, Z.G., Dong, Z.Q., Yuan, X.J., 2006. Fronts and strong currents of the upper southeast Indian Ocean. Acta Oceanologica Sinica 25 (2), 1-24. Available at http://www.hyxb.org.cn/aosen/ch/reader/create aspx?file no=20060201\&flag=1\&journal id=aosen\&year id=2006.

Heath, R.A., 1981. Oceanic fronts around southern New Zealand. Deep-Sea Research 28 (6), 547560. https://doi.org/10.1016/0198-0149(81)90116-3.

Heywood, K.J., King, B.A., 2002. Water masses and baroclinic transports in the South Atlantic and Southern Oceans. Journal of Marine Research 60 (5), 639-676. https://doi.org/10.1357/002224002762688687.

Holliday, N.P., Read, J.F., 1998. Surface oceanic fronts between Africa and Antarctica. Deep-Sea Research Part I 45 (2-3), 217-238. https://doi.org/10.1016/S0967-0637(97)00081-2.

Hopkins, J.E., 2008. Statistical modelling and variability of the Subtropical Front, New Zealand. PhD Thesis. University of Southampton, School of Ocean and Earth Science, $224 \mathrm{pp}$.

Hopkins, J., Shaw, A.G.P., Challenor, P., 2010. The Southland Front, New Zealand: Variability and ENSO correlations. Continental Shelf Research 30 (14), 1535-1548. https://doi.org/10.1016/i.csr.2010.05.016. 
Horn, P.L., Maolagáin, C., 2021. The growth and age structure of Chilean jack mackerel (Trachurus murphyi) following its influx to New Zealand waters. Journal of Fish Biology 98 (4), 11441154. https://doi.org/10.1111/ifb.14647.

James, C., Tomczak, M., Helmond, I., Pender, L., 2002. Summer and winter surveys of the Subtropical Front of the southeastern Indian Ocean 1997-1998. Journal of Marine Systems 37 (1-3), 129-149. https://doi.org/10.1016/S0924-7963(02)00199-9.

Jeffrey, M.Z., 1986. Climatological features of the Subtropical Convergence in Australian and New Zealand waters. Ocean Sciences Institute Report No. 17. University of Sydney, 95 pp.

Juliano, M.F., Alves, M.L.G.R., 2007. The Atlantic Subtropical Front/Current Systems of Azores and St. Helena. Journal of Physical Oceanography 37 (11), 2573-2598. https://doi.org/10.1175/2007JP03150.1.

Karstensen, J., 2004. Formation of the South Pacific shallow salinity minimum: A Southern Ocean pathway to the Tropical Pacific. Journal of Physical Oceanography 34 (11), 2398-2412. https://doi.org/10.1175/JPO2634.1.

Kobashi, F., Mitsudera, H., Xie, S.-P., 2006. Three subtropical fronts in the North Pacific: Observational evidence for mode water-induced subsurface frontogenesis. Journal of Geophysical Research: Oceans 111 (C9), C09033. https://doi.org/10.1029/2006JC003479.

Koshlyakov, M.N., Tarakanov, R.Yu., 2005. Intermediate water masses in the southern part of the Pacific Ocean. Oceanology 45 (4), 455-473.

Kostianoy, A.G., Ginzburg, A.I., Frankignoulle, M., Delille, B., 2004. Fronts in the Southern Indian Ocean as inferred from satellite sea surface temperature data. Journal of Marine Systems 45 (1-2), 55-73. https://doi.org/10.1016/i.jmarsys.2003.09.004.

Krümmel, O., 1882. Bemerkungen über die Meeresströmungen und Temperaturen in der Falklandsee. Aus dem Archiv der Deutschen Seewarte 5 (2), 1-24. https://babel.hathitrust.org/cgi/pt?id=uc1.\$c174314\&view=1up\&seq=5.

Lavers, J.L., Bond, A.L., 2017. Exceptional and rapid accumulation of anthropogenic debris on one of the world's most remote and pristine islands. Proceedings of the National Academy of Sciences of the United States of America 114 (23), 6052-6055. https://doi.org/10.1073/pnas.1619818114.

Li, G., Zou, X.R., Chen, X.J., Zhou, Y.Q., Zhang, M., 2013. Standardization of CPUE for Chilean jack mackerel (Trachurus murphyi) from Chinese trawl fleets in the high seas of the Southeast Pacific Ocean. Journal of Ocean University of China 12 (3), 441-451. https://doi.org/10.1007/s11802-013-1987-1.

Li, G., Cao, J., Zou, X.R., Chen, X.J., Runnebaum, J., 2016. Modeling habitat suitability index for Chilean jack mackerel (Trachurus murphyi) in the South East Pacific. Fisheries Research 178, 47-60. https://doi.org/10.1016/j.fishres.2015.11.012.

Lima, M., Canales, T.M., Wiff, R., Montero, J., 2020. The interaction between stock dynamics, fishing and climate caused the collapse of the jack mackerel stock at Humboldt Current ecosystem. Frontiers in Marine Science 7, 123. https://doi.org/10.3389/fmars.2020.00123.

Luis, A.J., Sudhakar, M., 2009. Upper-ocean hydrodynamics along meridional sections in the southwest Indian sector of the Southern Ocean during austral summer 2007. Polar Science 3 (1), 13-30. https://doi.org/10.1016/i.polar.2009.03.001.

Lutjeharms, J.R.E., Valentine, H.R., Van Ballegooyen, R.C., 1993. On the Subtropical Convergence in the South Atlantic Ocean. South African Journal of Science 89 (11-12), 552-559. 
Maes, C., Grima, N., Blanke, B., Martinez, E., Paviet-Salomon, T., Huck, T., 2018. A surface "superconvergence" pathway connecting the South Indian Ocean to the subtropical South Pacific gyre. Geophysical Research Letters 45 (4), 1915-1922. https://doi.org/10.1002/2017GL076366.

McCartney, M.S., Donohue, K.A., 2007. A deep cyclonic gyre in the Australian-Antarctic Basin. Progress in Oceanography 75 (4), 675-750. https://doi.org/10.1016/i.pocean.2007.02.008.

McCleave, J.D., 1993. Physical and behavioural controls on the oceanic distribution and migration of leptocephali. Fish Biology 43 (sA), 243-273. https://doi.org/10.1111/i.10958649.1993.tb01191.x.

McGinnis, R.F., 1974. Counterclockwise circulation in the Pacific subantarctic sector of the $\begin{array}{lllll}\text { Southern } & \text { Ocean. } & \text { Science } & 186 & \text { (4165), }\end{array}$ https://doi.org/10.1126/science.186.4165.736.

Mémery, L., Arhan, M., Alvarez-Salgado, X.A., Messias, M.-J., Mercier, H., Castro, C.G., Rios, A.F., 2000. The water masses along the western boundary of the south and equatorial Atlantic. Progress in Oceanography 47 (1), 69-98. https://doi.org/10.1016/S0079-6611(00)00032-X.

Miller, M.J., McCleave, J.D., 1994 Species assemblages of leptocephali in the Subtropical Convergence Zone of the Sargasso Sea. Journal of Marine Research 52 (4), 743-772. https://doi.org/10.1357/0022240943076948.

Munk, P., Hansen, M.M., Maes, G.E., Nielsen, T.G., Castonguay, M., Riemann, L., Sparholt, H., Als, T.D., Aarestrup, K., Andersen, N.G., Bachler, M., 2010. Oceanic fronts in the Sargasso Sea control the early life and drift of Atlantic eels. Proceedings of the Royal Society B: Biological Sciences 277 (1700), 3593-3599. https://doi.org/10.1098/rspb.2010.0900.

Neshyba, S., Fonseca, T.R., 1980. Evidence for counterflow to the West Wind Drift off South America. Journal of Geophysical Research $85 \quad$ (C9), 4888-4892. https://doi.org/10.1029/JC085iC09p04888. Get

Núñez, S., Letelier, J., Donoso, D., Sepúlveda, A., Arcos, D., 2004. Relating spatial distribution of Chilean jack mackerel and environmental factors in the oceanic waters off Chile. Gayana 68 (2), 444-449. https://doi.org/10.4067/S0717-65382004000300023.

Núñez, S., Vásquez, S., Ruiz, P., Sepúlveda, A., 2010. Distribution of early developmental stages of jack mackerel in the Southeastern Pacific Ocean. Technical Report, Chilean Jack Mackerel Workshop \#2. 11 pp. <https://www.sprfmo.int/assets/Meetings/Meetings-before2013/Scientific-Working-Group/Jack-Mackerel-Workshop-2008/02.CHJMWSDistributionof-early-developmental-stages-of-jackmackerel-in-the.pdf $>$.

Oke, P.R., Roughan, M., Cetina-Heredia, P., Pilo, G.S., Ridgway, K.R., Rykova, T., Archer, M.R., Coleman, R.C., Kerry, C.G., Rocha, C., Schaeffer, A., Vitarelli, E., 2019a. Revisiting the circulation of the East Australian Current: Its path, separation, and eddy field. Progress in Oceanography 176, 102139. https://doi.org/10.1016/j.pocean.2019.102139.

Oke, P.R., Pilo, G.S., Ridgway, K., Kiss, A., Rykova, T., 2019b. A search for the Tasman Front. Journal of Marine Systems 199, 103217. https://doi.org/10.1016/j.jmarsys.2019.103217.

Orsi, A.H., Whitworth III, T., Nowlin Jr., W.D., 1995. On the meridional extent and fronts of the Antarctic Circumpolar Current. Deep-Sea Research Part I 42 (5), 641-673. https://doi.org/10.1016/0967-0637(95)00021-W.

Parada, C., Gretchina, A., Vásquez, S., Belmadani, A., Combes, V., Ernst, B., Di Lorenzo, E., Porobic, J., Sepúlveda, A., 2017. Expanding the conceptual framework of the spatial population 
structure and life history of jack mackerel in the eastern South Pacific: an oceanic seamount region as potential spawning/nursery habitat. ICES Journal of Marine Science 74 (9), 23982414. https://doi.org/10.1093/icesjms/fsx065.

Peterson, R.G., Stramma, L., 1991. Upper-level circulation in the South Atlantic Ocean. Progress in Oceanography 26 (1), 1-73. https://doi.org/10.1016/0079-6611(91)90006-8.

Peterson, R.G., Stramma, L., Kortum, G., 1996. Early concepts and charts of ocean circulation. Progress in Oceanography 37 (1), 1-115. https://doi.org/10.1016/S007(96)80002-4.

Ridgway, K.R., 2007. Seasonal circulation around Tasmania: An interface between eastern and western boundary dynamics. Journal of Geophysical Research: Oceans 112 (10), C10016. https://doi.org/10.1029/2006JC003898.

Ridgway, K.R., Dunn, J.R., 2003. Mesoscale structure of the mean East Australian Current System and its relationship with topography. Progress in Oceanography 56 (2), 189-222. https://doi.org/10.1016/S0079-6611(03)00004-1.

Ridgway, K.R., Dunn, J.R., 2007. Observational evidence for a Southern Hemisphere oceanic supergyre. Geophysical Research Letters $34 \quad$ (13), L13612. https://doi.org/10.1029/2007GL030392.

Rowden, A.A., Anderson, O.F., Georgian, S.E., Bowden, D.A., Clark, M.R., Pallentin, A., Miller, A., 2017. High-resolution habitat suitability models for the conservation and management of vulnerable marine ecosystems on the Louisville Seamount Chain, South Pacific Ocean. Frontiers in Marine Science 4, Article 335. https://doi.org/10.3389/fmars.2017.00335.

Rusciano, E., Speich, S., Ollitrault, M., 2012. Interocean exchanges and the spreading of Antarctic Intermediate Water south of Africa. Journal of Geophysical Research: Oceans 117 (C10), C10010. https://doi.org/10.1029/2012JC008266.

Saldías, G.S., Sobarzo, M., Quiñones, R., 2019. Freshwater structure and its seasonal variability off western Patagonia. Progress in Oceanography 174, 143-153. https://doi.org/10.1016/j.pocean.2018.10.014.

Schneider, W., Fuenzalida, R., Rodríguez-Rubio, E., Garcés-Vargas, J., Bravo, L., 2003. Characteristics and formation of eastern South Pacific Intermediate Water. Geophysical Research Letters 30 (11), 1581. https://doi.org/10.1029/2003GL017086.

Serra, R., 1991. Important life history aspects of the Chilean jack mackerel, Trachurus symmetricus murphyi. Investigation Pesquera (Chile) 36, 67-83.

Shaw, A.G.P., Vennell, R., 2001. Measurements of an oceanic front using a front-following algorithm for AVHRR SST Imagery. Remote Sensing of Environment 75 (1), 47-62. https://doi.org/10.1016/S0034-4257(00)00155-3.

Smith, R.O., 2017. Variability of the Subtropical Front in the Tasman Sea. PhD Thesis. University of Otago, Dunedin, New Zealand, 256 pp.

Smith, R.O., Vennell, R., Bostock, H.C., Williams, M.J.M., 2013. Interaction of the subtropical front with topography around southern New Zealand. Deep-Sea Research Part I 76, 13-26. https://doi.org/10.1016/i.dsr.2013.02.007.

Smythe-Wright, D., Chapman, P., Duncombe Rae, C., Shannon, L.V., Boswell, S.M., 1998. Characteristics of the South Atlantic subtropical frontal zone between $15^{\circ} \mathrm{W}$ and $5^{\circ} \mathrm{E}$. Deep Sea Research Part I 45 (1), 167-192. https://doi.org/10.1016/S0967-0637(97)00068-X. 
Sokolov, S., Rintoul, S., 2000. Circulation and water masses of the southwest Pacific: WOCE section P11, Papua New Guinea to Tasmania. Journal of Marine Research 58 (2), 223-268. https://doi.org/10.1357/002224000321511151.

Sokolov, S., Rintoul, S.R., 2002. Structure of Southern Ocean fronts at $140^{\circ}$ E. Journal of Marine Systems 37 (1-3), 151-184. https://doi.org/10.1016/S0924-7963(02)00200-2.

Soldat, V.T., Kolomeiko, F.V., Glubokov, A.I., Nesterov, A.A., Chernyshkov, P.P., Timokhin, E.N., 2008. Jack mackerel (Trachurus murphyi) distribution peculiarities in the high seas of the South Pacific in relation to the population structure. Presented at the 2008 Chilean Jack Mackerel Workshop, Santiago, Chile. https://www.slideserve.com/file-download/3705714.

Stanton, B.R., 1979. The Tasman Front. New Zealand Journal of Marine and Freshwater Research 13 (2), 201-214. https://doi.org/10.1080/00288330.1979.9515795.

Stanton, B.R., 1981. An oceanographic survey of the Tasman Front. New Zealand Journal of $\begin{array}{lllll}\text { Marine and } & \text { Freshwater } & \text { 289-297. }\end{array}$ https://doi.org/10.1080/00288330.1981.9515924.

Stanton, B.R., Ridgway, N.M., 1988. An oceanographic survey of the subtropical convergence zone in the Tasman Sea. New Zealand Journal of Marine and Freshwater Research 22 (4), 583-593. https://doi.org/10.1080/00288330.1988.9516328.

Stevens, C.L., O’Callaghan, J.M., Chiswell, S.M., Hadfield, M.G., 2021. Physical oceanography of New Zealand/Aotearoa shelf seas - a review. New Zealand Journal of Marine and Freshwater Research 55 (1), 6-45. https://doi.org/10.1080/00288330.2019.1588746.

Stramma, L., 1992. The South Indian Ocean Current. Journal of Physical Oceanography 22 (4), 421-430. https://doi.org/10.1175/1520-0485(1992)022<0421:TSIOC>2.0.CO;2.

Stramma, L., Lutjeharms, J.R.E., 1997. The flow field of the subtropical gyre of the South Indian Ocean. Journal of Geophysical Research: Oceans 102 (C3), 5513-5530. https://doi.org/10.1029/96JC03455.

Stramma, L., Peterson, R.G., 1990. The South Atlantic Current. Journal of Physical Oceanography 20 (6), 846-859. https://doi.org/10.1175/1520-0485(1990)020<0846:TSAC>2.0.CO;2.

Stramma, L., Peterson, R.G., Tomczak, M., 1995. The South Pacific Current. Journal of Physical Oceanography $25 \quad$ (1), 77-91. $\quad$ https://doi.org/10.1175/15200485(1995)025<0077:TSPC>2.0.CO;2.

Sutton, P., 2001. Detailed structure of the Subtropical Front over Chatham Rise, east of New Zealand. Journal of Geophysical Research: Oceans 106 (C12), 31045-31056. https://doi.org/10.1029/2000jc000562.

Sutton, P.J.H., 2003. The Southland Current: A subantarctic current. New Zealand Journal of $\begin{array}{llll}\text { Marine and } & \text { Freshwater }\end{array}$ https://doi.org/10.1080/00288330.2003.9517195.

Szymanska, K., Tomczak, M., 1994. Subduction of Central Water near the Subtropical Front in the southern Tasman Sea. Deep-Sea Research Part I 41 (9), 1373-1386. https://doi.org/10.1016/0967-0637(94)90103-1.

Taylor, P.R., 2002. Stock structure and population biology of the Peruvian jack mackerel, Trachurus symmetricus murphyi. New Zealand Fisheries Assessment Report 2002/21, 78 pp. https://fs.fish.govt.nz/Page.aspx?pk=113\&dk=17417.

Tilburg, C.E., Hurlburt, H.E., O'Brien, J.J., Shriver, J.F., 2001. The dynamics of the East Australian Current System: the Tasman Front, the East Auckland Current, and the East Cape Current. 
Journal of Physical Oceanography 31 (10), 2917-2943. https://doi.org/10.1175/15200485(2001)031<2917:TDOTEA>2.0.CO;2.

Tilburg, C.E., Hurlburt, H.E., O'Brien, J.J., Shriver, J.F., 2002. Remote topographic forcing of a baroclinic western boundary current: An explanation for the Southland Current and the pathway of the subtropical front east of New Zealand. Journal of Physical Oceanography 32 (11), 3216-3232. https://doi.org/10.1175/1520-0485(2002)032<3216:RTFOAB>2.0.CO;2.

Tippins, D., Tomczak, M., 2003. Meridional Turner angles and density compensation in the upper ocean. Ocean Dynamics 53 (4), 332-342. https://doi.org/10.1007/s10236-003-0056-5.

Tsuchiya, M., Talley, L.D., McCartney, M.S., 1994. Water-mass distributions in the western South Atlantic; a section from South Georgia Island (54S) northward across the equator. Journal of Marine Research 52 (1), 55-81. https://doi.org/10.1357/0022240943076759.

Tsuchiya, M., Talley, L.D., 1996. Water-property distributions along an eastern Pacific hydrographic section at 135W. Journal of Marine Research 54 (3), 541-564. https://doi.org/10.1357/0022240963213583.

Tsuchiya, M., Talley, L.D., 1998. A Pacific hydrographic section at $88^{\circ} \mathrm{W}$ : Water-property distribution. Journal of Geophysical Research: Oceans 103 (C6), 12899-12918. https://doi.org/10.1029/97JC03415.

Uddstrom, M.J., Oien, N.A., 1999. On the use of high-resolution satellite data to describe the spatial and temporal variability of sea surface temperatures in the New Zealand region. Journal of Geophysical Research: Oceans 104 (C9), 20729-20751. https://doi.org/10.1029/1999JC900167.

Uribe, E., Neshyba, S., Fonseca, T., 1982. Phytoplankton community composition across the West Wind Drift off South America. Deep Sea Research 29 (10), 1229-1243. https://doi.org/10.1016/0198-0149(82)90092-9.

Vásquez, S., Correa-Ramírez, M., Parada, C., Sepúlveda, A., 2013. The influence of oceanographic processes on jack mackerel (Trachurus murphyi) larval distribution and population structure in the southeastern Pacific Ocean. ICES Journal of Marine Science 70 (6), 1097-1107. https://doi.org/10.1093/icesjms/fst065.

Villareal, T.A., Wilson, C., 2014. A comparison of the Pac-X Trans-Pacific Wave Glider data and satellite data (MODIS, Aquarius, TRMM and VIIRS). PloS ONE 9 (3), e92280. https://doi.org/10.1371/journal.pone.0092280.

Vinogradov, M.E., Flint, M.V. (editors), 1988. Ecosystems of the Subantarctic Zone of the Pacific Ocean. Nauka, Moscow, 304 pp. (in Russian); English translation: Pacific Subantarctic Ecosystems. New Zealand Translation Centre Ltd., Wellington, 1997, 243 pp. http://docs.niwa.co.nz/library/public/pacific-subant-eco.

Voorhis, A.D., 1969. The horizontal extent and persistence of thermal fronts in the Sargasso Sea. Deep-Sea Research 16 (Supplement), 331-337.

Wong, A.P.S., Johnson, G.C., 2003. South Pacific Eastern Subtropical Mode Water. Journal of Physical Oceanography 33 (7), 1493-1509. https://doi.org/10.1175/15200485(2003)033<1493:SPESMW>2.0.CO;2.

Zhang, H., Zhang, S.-M., Cui, X.-S., Yang, S.-L., Hua, C.-J., Ma, H.-Y., 2015. Spatio-temporal dynamics in the location of the fishing grounds and catch per unit effort (CPUE) for Chilean jack mackerel (Trachurus murphyi Nichols, 1920) from Chinese trawl fleets on the high seas 
of the Southeast Pacific Ocean, 2001-2010. Journal of Applied Ichthyology 31 (4), 646-656. https://doi.org/10.1111/jai.12765.

Zhu, G.P., Zhang, M., Ashford, J., Zou, X.R., Chen, X.J., Zhou, Y.Q., 2014. Does life history connectivity explain distributions of Chilean jack mackerel Trachurus murphyi caught in international waters prior to decline of the southeastern Pacific fishery? Fisheries Research 151, 20-25. https://doi.org/10.1016/i.fishres.2013.11.013. 